\title{
INTRODUÇÃ̃O À OBRA DE PETER F. DRUCKER
}

JoÃo Bosco LODI *

Peter F. Drucker vive em Montclair, lugarejo do Estado de Nova Jersey, num ambiente típico da Nova Inglaterra, a trinta minutos de carro da cidade de Nova Iorque. Sua casa fica numa das estradas que circundam a montanha que dá atração ao lugar. Ali vive só com sua espôsa, pois os seus quatro filhos maiores moram em lugares distantes, como a Califórnia ou Lima, no Peru. A senhora DRUCKer é física, tem uma vasta cultura e colabora com o marido na preparação de seus livros, como se pode perceber nos diversos prefácios. Peter F. DRUCKer tem escritório na Escola de Administração de Emprêsas da Universidade de Nova Iorque, onde é professor; mas seu trabalho de criação é feito em Montclair, num pequeno estúdio onde há poucos livros, um ditafone e muitas telas japonêsas. DRUCKER é um grande colecionador de telas japonêsas clássicas, de alto valor. Além dêsse hobby, êle é, com tôda a família, alpinista; tem escalado não só as Rocky Mountains no Colorado, onde tem uma casa, mas até as montanhas de Hokaido no Norte do Japão. DRUCkER impressiona pela vasta cultura de história, filosofia e até teologia,

* Bacharel em Filosofia pela Universidade Gregoriana de Roma e licenciado em Filosofia pela Universidade de São Paulo. Consultor para Desenvolvimento de Executivos num grupo de emprêsas brasileiras. 
e não apenas por seus sólidos conhecimentos de economia, finanças e administração: uma pessoa educada na típica formação humanística européia. Seus artigos e livros são preparados com auxílio do ditafone, e não à máquina ou à mão. Uma secretária do lugar transcreve o ditado para os textos que são, em seguida, reescritos. $O$ texto original vai sendo enriquecido de "casos" que DRUCKER extrai da experiência como consultor. Os artigos fornecem matériaprima para os livros, assim como os casos de consultoria para os artigos.

Êste breve retrato foi-me fornecido por um primo da senhora Drucker, que trabalha em São Paulo, Dr. RoBERTo Kohlmann, Gerente de Desenvolvimento de Produtos da SANBRA, o qual também me possibilitou entrevistar o autor num dia de janeiro de 1968 quando êste veio ao Brasil numa visita exclusivamente familiar.

O presente trabalho foi preparado com a intenção de fornecer ao estudioso da Administração uma introdução à obra de DRUCKER. Como muitos brasileiros, "descobri" DRUCKER há menos de dez anos e, desde aquela época, fiquei encantado com as perspectivas abertas para a compreensão da emprêsa industrial, com o originalidade de suas idéias e com a influência educativa da leitura de seus livros. Êste artigo desenvolve-se através da análise cronológica das obras de DRUCKER e conclui com uma tentativa de sintese.

\section{DADOS BIOGRÁFICOS}

Peter F. Drucker é escritor, consultor e professor de administração de emprêsas. Como consultor, êle é especializado em políticas de negócios e em organização da alta administração. Êle tem sido consultor para várias das maiores emprêsas dos Estados Unidos e do mundo. Tem sido também consultor de agências do govêrno norteamericano e de diversos outros governos, tais como o do Canadá e do Japão. $O$ mesmo trabalho êle tem prestado a instituições públicas, como universidades e hospitais. Tem escrito diversos livros sôbre assuntos políticos e eco- 
nômicos. Entre outros, podem ser citados $A$ Nova Sociedade (1950), Prática de Administração de Emprêsas (1954), The America's Next Twenty Years (1957), Fronteiras do Amanhã (1959), Managing for Results ${ }^{1}$ (1964), ganhador do prêmio McKinsey da Academia Norte-Americana de Administração, e The Effective Executive (1967). Segundo o próprio autor me informou, um nôvo livro deverá sair nos próximos anos. Será uma obra desenvolvendo os temas de Fronteiras do Amanhã. O editor alemão de DRUCKER publicou um livro contendo suas reflexões colhidas em conferências e discursos. ${ }^{2}$ Trata-se de uma coleção de temas como Política, Administração de Emprêsas, História, Filosofia, Política Econômica e até Pedagogia, colhidos de artigos, conferências e discursos como paraninfo de formatura. Três partes compõem a obra:

- Idéias para o Futuro,

- Política Econômica e Sociedade, e

- Retratos do Presente.

$O$ editor japonês publicou uma interessante antologia contendo textos escolhidos de suas obras.

DRUCKER contribui freqüentemente para as maiores revistas dos Estados Unidos tais como Harvard Business Review, Fortune, Science, Harpers, Nation's Business, The New York Times Magazine. Perguntado a respeito dêsses artigos, DRUCKer informou que êles são posteriormente reformulados e fundidos nos livros que publica e que, portanto, uma bibliografia de seus artigos não acrescenta muito ao que diz em seus livros.

Como professor e como sócio de entidades profissionais, sua atividade é muito variada. É professor de Administração de Emprêsas na Escola de Administração de Emprêsas da Universidade de Nova Iorque. É sócio da Asso-

\footnotetext{
1 Recentemente traduzido em português com o título de Administração Lucrativa, Rio de Janeiro, Zahar Editôres, 1968.

2 DRUCKER, Gedanken für die Zukunft (Pensando no Futuro), Düsseldorf, ECON Verlag, 1959.
} 
ciação Americana para o Progresso da Ciência, sócio da Academia Internacional de Administração, da American Academy of Management, sócio honorário do British Institute of Management, e conselheiro do Logistics $\mathrm{Ma}$ nagement Institute. Foi presidente da Sociedade para a História da Tecnologia, em 1965/66.

Nascido em 1909, em Viena, formou-se bacharel em Direito na Austria. Doutorou-se em Direito Público e Internacional na Universidade de Frankfurt (Alemanha). Pertenceu ao corpo editorial do Frankfurter General Anzeiger até o advento do nazismo (1933), quando se mudou para a Inglaterra onde prosseguiu estudos de economia. Foi economista de uma organização bancária internacional com sede em Londres, economista nos Estados Unidos para um grupo de Bancos e sociedades inglêsas de investimentos e européias, correspondente americano para um grupo de jornais inglêses, e professor de Política e Filosofia no Bennington College (Vermont). Durante a Segunda Guerra Mundial, realizou um estudo de organização na General Motors que se tornou um livro clássico de análise da grande organização: The Concept of the Corporation publicado em 1964.

Recebeu em 1963 a medalha Wallace Clark de Administração Internacional, medalha da American Marketing Association, medalha de ouro da Universidade Internacional de Estudos Sociais, Roma (Itália), medalha de ouro da Associação Italiana de Administração de Emprêsas, a medalha Christian Culture da Universidade Assumption, Ontário (Canadá), e o prêmio Hagemann (Alemanha) em 1966. Tem doutorado honorário em Pace College (Nova Iorque), Universidade Nihon (Tóquio), Universidade de Wayne (Detroit).

AS PRIMEIRAS OBRAS

Publicados antes do fim da Segunda Guerra Mundial, seus primeiros trabalhos são: The End of the Economic 
Man, ${ }^{3} 1939$ e The Future of the Industrial Man, ${ }^{4} 1943$. As teses centrais dêsses dois livros estão ainda distantes dos temas que passaram mais tarde a constituir o centro de suas preocupações. Influenciado pelo seu doutoramento em Direito Público e Internacional, o ponto de vista do autor é o de um jurista desenvolvendo o tema da legalidade do poder e o sistema de status na moderna corporação industrial. Examinemos de passagem os temas principais dessas primeiras obras.

A grande corporação abrangendo fábricas de produção em massa está emergindo como instituição representativa da sociedade. Representativo não significa necessàriamente preponderante em número. Representativo é aquilo que se identifica com o espírito do tempo e uma das características de nosso tempo é a grande emprêsa industrial. Ora, a ascensão dessas instituições econômicas não estará completa enquanto elas não representarem valôres largamente reconhecidos pelo homem de hoje. Um dêsses valores é a crença na liberdade e na igualdade de condições. Enquanto o capitalismo espera que uma sociedade livre resulte do conceito de lucro "como um legislador supremo do comportamento social", o socialismo tem sua dinâmica na idéia de uma sociedade sem classes, afirmando o princípio de igualdade de condições. Porém, tanto o capitalismo como o socialismo não conseguiram atingir o ideal da liberdade e igualdade que é o ideal do Ocidente. A emprêsa industrial está se desenvolvendo e criando em tôrno de si uma sociedade industrial, sem vinculações com as ideologias até agora predominantes. Essa "Sociedade Funcional" (Functioning Society), cada vez menos subordinada às ideologias atuais, terá que equacionar três tipos principais de problemas:

que todo indivíduo tenha uma função social definida em vista de sua ocupação;

\footnotetext{
3 DRUCKER, Peter F., The End of the Economic Man, Londres, Heineman, 1939.

- Drucker, Peter F., The Concept of the Corporation, Nova Iorque, Heineman, 1943.
} 
- que todo indivíduo tenha um status social reconhecido;

- que a distribuição do poder social seja legitimada.

Vejamos a questão da legitimidade do poder da gerência. No início, pensava-se que o poder da gerência da emprêsa derivava dos direitos de propriedade. Era um poder delegado pelos proprietários das ações da emprêsa. Êsse conceito não é mais certo. $\mathrm{O}$ poder dos gerentes não é controlado pelos possuidores da propriedade, pois os acionistas, pràticamente, não podem exercer seus direitos. $O$ acionista abdicou conscientemente de seu poder. Então, - poder da gerência não advém da delegação dos proprietários. Ora, se êsse poder não advém dos acionistas e não é aceito pela sociedade, não tem fundamento, é ilegítimo e irresponsável. No entanto, a gerência das emprêsas industriais exerce uma influência social marcante em nossa época e, por isso, precisa ser legitimada.

A legitimação do poder gerencial dar-se-á quando os valôres sociais forem desenvolvidos dentro da emprêsa industrial, dando à corporação um propósito social. A corporação precisa ter em vista, não apenas a eficiência técnica, mas, também a eficiência moral. Precisa ser organizada de modo a cumprir suas obrigações sociais, ao mesmo tempo que procura seus interêsses econômicos. As crenças e valôres da sociedade precisam ser realizados pela corporação, porque ela é uma das principais instituições de nossa época. Êsses valôres fundamentais são a igualdade de oportunidades e a dignidade individual decorrente de um status definido. Só então, a instituição industrial derivará sua autoridade de um princípio moral e poderá sofrer sanções do poder social. Se isso não acontecer, a sociedade industrial, tal como a conhecemos hoje, se desintegrará e será substituída por uma sociedade totalitária. Essa última dará aos indivíduos um status independente do processo produtivo. 
Esta temática irá se consolidando nas obras seguintes de DRUCKer. Ao mesmo tempo, sua atenção irá se concentrando mais na eficiência dos dirigentes da organização. No livro seguinte, The Concept of the Corporation encontra-se uma frase que resume essa preocupação anterior: "A moderna emprêsa de negócios não é apenas uma instituição econômica; ela deve ter um conceito atrás de si, uma organização e uma constituição. Ela é uma instituição social e uma comunidade e, como tal, deve ser dirigida $~$ estudada."

\section{A CORPORAÇÃO COMO ESFÔRÇO HUMANO}

Em 1946, saiu a primeira obra característica de PETER F. DRUCKER, The Concept of the Corporation. ${ }^{5}$ Esse livro foi um dos estudos clássicos sôbre a organização da General Motors e é comparável a outra obra que surgiu quase vinte anos após, Minha Vida na General Motors, de A. SloAN JR. ${ }^{6}$ A General Motors era um tema tentador para todos os estudiosos, pois era um símbolo desta grande corporação que caracteriza nossa época. Vivemos na idade das grandes organizações. "O homem parece ter-se tornado anão pelas montanhas gigantes das grandes organizações ao seu redor. Aí está o monte Everest do govêrno moderno. Ao lado dêle, as fôrças armadas que em todo o país devoram a parte do leão da produção nacional. Vêm, então, os picos das grandes corporações e, não menos altos $e$ difíceis, os picos dos grandes e poderosos sindicatos; aí as vastas universidades, os grandes hospitais - tôdas criaturas dêste século."

DRUCKer explica, no prefácio, as razões que o levaram a êsse estudo. A General Motors, a maior emprêsa manufatureira do mundo, não começou como a Ford, sua concorrente, como um pequeno empreendimento individual. Começou já como grande emprêsa aglomerando diversos

\footnotetext{
5 DRUCKer, Peter F., Concept of the Corporation, New York, John Day, 1946.

- Sloan JR., Alfred, Minha Vida na Genera' Motors. Rio de Janeiro, tradução portuguêsa da Ed. Record, 1963.
} 
pequenos empreendimentos. A GM foi criada em 1910 por Willian C. DuRanT, um empreendedor que viu o futuro do automóvel e comprou logo cedo diversas pequenas companhias automobilísticas independentes. Com êsses pequenos empreendimentos vieram seus antigos donos, cada qual decidido a permanecer no contrôle daquilo que fôra "o seu" negócio. O grande impasse surgiu em 1921 quando, além da depressão do após-guerra, a General Motors decidiu desfazer-se dêsses pequenos caciques para organizar-se em base de gerência profissional. Havia muitas dúvidas sôbre essa decisão, mas o único dado certo era que a continuação do status quo tradicional levaria a emprêsa ao desastre. Em 1921, ALFRED P. SLOAN assumiu a liderança do negócio num período longo até 1955 . Seu programa de trabalho, em cinco anos, elevou a Companhia ao primeiro lugar na indústria automobilística americana. Êsse sucesso foi conseguido pela aplicação de certas políticas de negócio e certos princípios. A descoberta e consolidação dêsses princípios passaram a ser grande preocupação dos administradores dessa e de outras emprêsas. É assim que DRUCKer vai encontrar a General Motors. No início da Segunda Guerra Mundial, êle procurava uma emprêsa onde pudesse estudar a estrutura da organização, a ordem social e as suposições básicas. Em 1943, recebeu o convite para estudar as diretrizes administrativas e organização da GM, do ponto de vista de um consultor externo, e produzir um relatório para a Direção. Trabalhou afincadamente durante 18 meses, entrevistando a maioria dos dirigentes e lendo grande parte dos documentos acumulados por essa organização. Após entrega do relatório para a alta administração, trabalhou ainda algum tempo, desenvolvendo as idéias dêsse relatório. $O$ manuscrito completo do livro estava pronto alguns dias após a renđição alemã em 1945.

O livro, que saiu em 1946, divulgou na época oportuna as idéias de descentralização na grande emprêsa e por isso causou impacto em tôdas as grandes corporações da época. Os historiadores da Ford, especialmente NEvins e HJLL, 
testemunharam que a remodelação dessa emprêsa, tirada do quase desastre por HENRY FORD II, sofreu o impacto do livro de DRUCKer. Alguns anos mais tarde, a General Electric indicava sinais de assimilação dessas novas idéias, especialmente na obra de CORDINER. ${ }^{7}$ Mesmo fora dos Estados Unidos, a obra de DRUCKER ajudou a divulgar as idéias de reforma da grande organização. $\mathrm{Na}$ Inglaterra a Imperial Chemical Ind. empreendeu, em 1963, uma reestruturação similar à da General Motors americana. Até na União Soviética, as idéias de descentralização começaram a surtir efeito durante o Govêrno de KRUCHEV. No início, a descentralização era temida e combatida porque parecia debilitar a administração central. Aos poucos, o livro foi ajudando a reduzir as reservas sôbre a descentralização, mostrando que ela era um meio de fortalecer a alta administração, permitindo-lhe tempo para concentrar-se nas tarefas-chave da organização.

$\mathrm{Na}$ primeira parte, intitulada "A Corporação como Esfôrço Humano", o autor analisa a organização da General Motors, sua descentralização e seus problemas mercadológicos. $\mathrm{Na}$ segunda parte, que tem como título "A Corporação como Instituição Social", o autor analisa os diversos níveis sociais da organização, fixando-se mais no nível de capatazia e supervisão. A corporação é identificada com o sistema de classes americano e especialmente com os valôres sociais da classe média. $\mathrm{Na}$ terceira parte, cujo título é "Políticas Econômicas", o autor analisa diversos problemas correlatos: a questão do tamanho, o monopólio, os objetivos de produção e os problemas da política de pleno emprêgo.

$\mathrm{Na}$ primeira parte do livro, vamos encontrar as principais idéias sôbre organização e descentralização. Fixemo-nos um pouco sôbre os problemas da organização da produção. Neste tema, o aspecto que mais chama a atenção do autor é o da formação da liderança industrial.

7 CoRdiner, Ralph, New Frontiers for Professional Managers, Nova Iorque, Mc-Graw-Hill Book Co., 1956. 
A primeira regra da corporação é a da sobrevivência como organização. Sendo êsse o objetivo básico, as diretrizes são os recursos gerenciais. A corporação precisa encontrar dentro de si mesma todos os talentos e habilidades de que necessita para atingir os resultados a que se propõe. Deve desenvolver tanto os especialistas, necessitados por serem instrumentos humanos de alto calibre, como os generalistas, que são as pessoas a cargo da direção, educadas e capazes para fazer julgamento e tomar decisões. A corporação deve obter dêles o melhor, enquanto luta para neutralizar suas fraquezas. A habilidade para o comando independente deve ser testada ainda num nível de cargo onde as falhas não sejam fatais. A seleção e o treinamento dos líderes é uma das questões centrais da corporação. Nessa fase de formação, um especial cuidado deve ser dado à elaboração de um estilo de liderança. Uma liderança industrial do tipo ditatorial não tem condições de funcionar por muito tempo sem profundos prejuízos para o moral interno. Há necessidade de se despertar a lealdade nos funcionários, e essa é incompatível com o poder discricionário e personalista. Para as pessoas daquele tempo, essas referências estão veladamente dirigidas ao tipo de liderança autocrática que FORD exercia nos últimos anos de direção de sua emprêsa, antes da transição para HENRY FORD II. Além de uma liderança voltada para resultados, a corporação deve preocupar-se em favorecer a tomada de decisão. A grande emprêsa tem uma tendência natural para desencorajar a iniciativa e premiar o conformismo dos jovens executivos.

Outro aspecto fundamental, na organização da grande corporação, é o sadio equilíbrio entre os principios e a prática. A emprêsa deve encontrar a harmonia entre a necessidade de ater-se a princípios sólidos adquiridos pela experiência de muitos anos e a adaptação requerida pelas contínuas mudanças. A insistência nos princípios e procedimentos põe em risco a flexibilidade da companhia. A insistência no pragmatismo leva ao desnorteio e às tentativas frustradas. A corporação é prêsa de paradoxos tais 
como êste: a corporação deve depender de sistemas formais de contabilidade que convidam ao desenvolvimento burocrático.

Os dois temas resumidos aqui, o estilo de liderança e os sistemas orientadores, serão desenvolvidos nas obras ulteriores de DRUCKER e aparecerão sempre como uma constante.

No segundo capítulo, cujo título é "Descentralização", encontram-se as mais iluminadas páginas do livro. Êsse capítulo é uma descrição analítica da descentralização da General Motors. O autor estuda os seus objetivos e como ficaram relacionadas a Administração Central e as Gerências Divisionais; mostra o fluxo da informação dos dois sentidos; analisa os resultados em têrmos da liberdade e ordem conseguidas; fecha o capítulo com a reafirmação da necessidade de medidas objetivas para avaliar o desempenho das divisões.

Os efeitos ou as vantagens que a descentralização deixou na General Motors foram assim apreciados por DRUCKER:

- A rapidez com que uma decisão é tomada; ausência de confusão em quem a toma; o conhecimento das políticas em que a decisão é fundada, por tôdas as pessoas envolvidas.

- A ausência de conflitos de interêsse entre as divisões e a General Motors.

O sentido de justiça no trato entre os executivos; a certeza de que um bom trabalho será apreciado; o sentimento de segurança quando as questões pessoais, intrigas e facciosismo são controlados.

A democracia da administração e sua informalidade. Não há dúvida de onde reside a autoridade. Todos são livres para criticar, para falar, para sugerir e, apesar disso, assim que uma decisão é tomada, ninguém tenta sabotá-la.

- A ausência de um vazio entre os "poucos privilegiados" e os "demais". 
Há um grande grupo de administradores. Mas há sempre um suprimento de bons e experientes líderes, prontos para tomar responsabilidades.

A descentralização significa que as divisões e os gerentes fracos não podem ir muito adiante à sombra das divisões bem sucedidas, tirando proveito de sua reputação.

A descentralização significa ausência de "administração por ordens", na qual ninguém sabe ao certo porque faz o que é mandado fazer. Seu lugar é tomado por discussões e políticas que são públicas e que chegaram como resultado da experiência de todos.

Ora, para que a descentralização seja realizada com o menor número de riscos, há necessidade de uma medida objetiva do desempenho e da eficiência. Eis o que diz o autor, na página 67 dêsse seu livro:

"Medindo a eficiência e o desempenho nas decisões e na administração com os critérios objetivos de custo e eficiência, de retôrno do capital investido, e de posição competitiva no mercado, a General Motors pretende a eliminação de elementos pessoais e subjetivos na relação entre chefe e subordinado, administração central e divisional. Questões como: quão eficiente é um homem, quão bem sucedido e quão importante êle é para a companhia, não precisam ser decididas na base da preferência subjetiva. De fato, elas simplesmente não deveriam ser decididas: elas deveriam ser claramente rspondidas pela medida objetiva que registra a eficiência e o desempenho, automàticamente. $O$ presidente da companhia não precisa dizer a um gerente divisional que não está satisfeito com êle; o gerente divisional sabe-o, de qualquer modo, olhando para os números de seu custo e análise do mercado. Similarmente, o presidente não precisa justificar uma promoção para os colegas do homem promovido; êle tem o registro do homem, que é conhecido dentro da companhia. Também a medida objetiva deveria limitar o elemento pessoal nas Jecisões de política. Se as opiniões e sugestões de um ho- 
mem não são aprovadas, isto não deveria acontecer por causa da posição superior do chefe, mas porque os fatos estão contra êle. Isso tornaria possível que os chefes admitissem erros diante de seus subordinados, talvez a coisa mais importante nas relações humanas. Enfim, essa medida objetiva não só tornaria possíveis as relações informais e amigas, um espírito de equipe e uma livre e franca discussão, como também tornaria natural e quase inevitável a organização da gerência como uma equipe numa base federativa, levantando fortes barreiras de fatos contra a ação baseada em nada mais do que a antigüidade e escalão."

Antes de terminar a análise de alguns aspectos dêste importante livro vejamos quais são as reflexões de DRUCKER sôbre a formação especializada versus formação generalista para executivos. As pessoas não deveriam poder permanecer como especialistas confinados ao conhecimento de um campo limitado. Deve-se treinar para a compreensão do todo em vez de treinar para a compreensão de determinadas partes. Um cargo executivo não deve ser oferecido a um especialista, seja lá qual fôr sua especialidade, enquanto o mesmo não tiver trabalhado em vários departamentos da emprêsa. As pessoas cujo potencial executivo fôsse identificado deveriam ser transferidas, por exemplo, do departamento de fabricação para o de vendas ou de pessoal, do trabalho de projetista para o de mestre e assim por diante. Em vez de recrutar fora, a emprêsa deve formar seu próprio grupo de executivos pelo método de rodizio de cargos, proporcionando-lhes um inteligente sistema de promoção e de substituição em férias. Só assim haverá dirigentes com visão de conjunto e familiarizados com cada parte do negócio.

The Concept of the Corporation, como fica demonstrado, é uma obra clássica de estudo da organização e deixou grande influência. No conjunto da obra de DRUCKER, The Concept é o ponto de partida para a compreensão de sua obra-prima, a Prática de Administração de Emprêsas. 
A NOVA SOCIEDADE

As idéias sôbre a comunidade fabril, que germinaram no livro anterior, encontram, na nova obra, um lugar para crescimento. Em 1950, é editada a obra seguinte: A Nova Sociedade. ${ }^{8}$ Como o próprio autor explica, "são dois os temas principais dêste livro. $O$ primeiro é que a sociedade industrial do século XX é uma sociedade inteiramente nova e peculiar, de âmbito mundial mais do que ocidental ou capitalista. $O$ segundo é que esta nova sociedade possui uma instituição específica: a emprêsa industrial, com a sua administração, sua comunidade fabril e seu irmão gêmeo, o sindicato trabalhista".

O livro, que saiu dois meses antes de os Estados UJnidos entrarem na guerra da Coréia, foi reeditado pelo autor doze anos depois. A guerra da Coréia modificou bastante a sociedade americana. A sociedade idealista de antes acreditava em dar soluções unilaterais para o mundo. Durante a guerra da Coréia veio a desilusão das soluções próprias e ela tornou-se uma sociedade crescentemente inquieta e atormentada.

A previsão feita por DRUCKER nesse livro acertou em muitos aspectos. Em outros, êle teve de rever seus pontos de vista. O mundo sofreu quatro desenvolvimentos após a edição dêsse livro:

- o dramático ressurgimento da Europa;

- a exigência de desenvolvimento econômico e social em todo o mundo;

- o aparecimento da classe média de assalariados, o trabalhador com conhecimentos técnicos;

- o surgimento da administração de emprêsas como uma função essencial da sociedade.

- Drucker, Peter F., A Nova Sociedade, Rio de Janeiro, tradução portuguêsa da Editôra Fundo de Cultura, 1964. 
Examinemos o que dizia DRUCKER em 1949 sôbre a Comunidade Fabril. "As exigências da emprêsa sôbre a comunidade fabril e as exigências da sociedade e do indivíduo estão em harmonia. A emprêsa tem de exigir que $c$ indivíduo assuma uma "atitude administrativa" para com seu emprêgo, seu trabalho e seu produto; mas isso importa no mesmo que a exigência da sociedade quanto à participação responsável do indivíduo como cidadão. A emprêsa tem de exigir a mais ampla utilização da capacidade e das ambições de seus empregados; sua exigência quanto a pessoas para preencherem cargos de chefia e de direção é pràticamente insaciável, o que significa que o interêsse da emprêsa e a exigência de oportunidades iguais correm paralelamente". ${ }^{9}$

Um dos aspectos da criação dessa "atitude administrativa" é dar ao empregado uma visão de conjunto da emprêsa e integrá-lo nos objetivos da mesma. "Para o trabalhador da produção em massa, manual ou não, o desejo de conhe. cer e compreender é um motivo primordial de ação. A maior contribuição do homem especializado é a sua arte em si; nela repousam, igualmente, seu orgulho e sua satisfação. As pessoas que não possuem a habilidade tradicional do artesanato têm seu orgulho, sua satisfação e sua contribuição na capacidade de integrar, de ver seu trabalho e o conjunto em suas mútuas relações e de encontrar a realização de sua exigência de status na "atitude administrativa". ${ }^{10}$

A velha escola tayloriana de administração científica pretendeu eliminar a atitude do operário como fator de produção e raramente ocorreu ao engenheiro industrial ou ao perito em sistemas que a atitude é um fator produtivo. A "atitude administrativa" entre os operários da produção conduz a um aumento quase explosivo da produtividade e eficiência. Essa atitude é ainda mais importante

Idem, ibidem, p. 174.

$10 \quad$ Idem, ibidem, p. 176. 
para a "nova classe média industrial" composta de inspetores, técnicos e gerentes intermediários. A habilidade da média administração é a capacidade de integrar.

"Nestes últimos anos, a administração norte-americana começou a compreender a importância que tem para a emprêsa êsse grupo médio e sua atitude. Mas até aqui poucas administrações compreendem que, de todos os grupos, a classe média industrial é a que acha mais difícil ver o conjunto e compreender sua própria função. $O$ trabalhador da produção em massa pelo menos se ocupa de algo tangível e imediato: um processo, um movimento, um produto. Maneja uma tira de metal, move uma alavanca, opera uma máquina. $O$ grupo médio manuseia plantas, elabora formulários de papel e manipula conceitos e algarismos - tudo altamente abstrato. $O$ operário trabalha num conjunto; o inspetor e o administrador médio, muitas vêzes, o técnico também, trabalham sós. 0 operário pode mostrar uma peça no produto acabado e dizer: eu coloquei esta peça. $O$ homem do grupo médio só pode dizer: "nós", sem ser realmente capaz de dizer a quem abrange êsse plural, nem onde êle próprio se encontra nesse coletivo. O próprio grupo que mais precisaria ter uma "atitude administrativa" é o que enfrenta as maiores dificuldades para consegui-la". ${ }^{11}$

O surgimento da média administração é um fato nôvo e importante. Em tôdas as sociedades pré-industriais apenas o trabalho manual é diretamente produtivo; daí, um homem que não faz tal trabalho ser uma carga para tôda a economia. A economia de uma sociedade pré-industrial está demasiado próxima da subsistência para permitir que mais do que uma pequeníssima fração da população deixe de ser imediatamente produtiva. Isto explica por que as civilizações pré-industriais degradaram com uma semiescravidão as suas classes inferiores. $\mathrm{Na}$ sociedade industrial, a administração é responsável pela melhor produção.

Idem, ibidem. p. 178. 
S̀eu trabalho não é considerado parasitário da produção, mas multiplicador desta. No programa de produção de guerra norte-americano, o maior estrangulamento não foi a escassez de materiais ou de mão-de-obra, mas a carência de técnicos médios de administração.

A própria natureza do trabalho fracionado veio a dificultar a integração. TAYLOR dividiu o trabalho para facilitar a éspecialização, e com isso dificultou a integração do homem e tirou dêle a idéia de criação: "Nós ainda temos que aprender como fazer a segunda metade do trabalho do qual TAYLOR e GANTT fizeram a primeira metade, há cinqüenta anos passados. Êles dividiram a operação em seus movimentos constituintes; nós teremos que juntar os movimentos outra vez para produzir uma operação que se baseie tanto no movimento elementar não-especializado quanto na capacidade e na necessidade especificamente humanas de coordenar". ${ }^{12}$

"O que o trabalhador precisa é ver a fábrica como se fôsse um gerente. Só assim êle pode ver qual a sua parte; da sua parte êle não pode alcançar o todo. Êsse ver não é questão de informações, de cursos de treinamento, de percorrer a fábrica em caráter de visita, ou processos semelhantes. $O$ que é preciso é a experiência real do conjunto através do trabalho individual". ${ }^{13}$

"A chave para a compreensão do problema, assim como para a sua solução, está em que não existe êsse problema para a alta administração, embora exista para a supervisão e para os escalões mais baixos da administração média, quase tanto quanto para as massas. Do ponto de vista da alta administração, o produto é òbviamente significativo. O motivo, é claro, reside em que a alta administração não vê abridores de lata nem abajures, mas um negócio com problemas de fabricação e de planejamento, de compra e de venda, de financiamento e de contabilidade, etc. $O$ trabalhador tem um interêsse patético em saber tanto quanto

Idem, ibidem, p. 190.

13 Idem, ibidem, p. 197. 
possível a respeito do negócio. Mas tôdas as nossas provas demonstram também que o trabalhador tanto não pode, do seu ângulo, ver o negócio "administrativamente", quanto não pode ver a relação do seu processo para com o trabalho do todo." 14

"Podemos dizer francamente que atualmente não há comunicação. Os grupos funcionais da emprêsa não se compreendem entre si; cada um dêles não imagina o que faz o outro nem por que o faz. O problema se apresenta geralmente como uma dificuldade de "comunicações entre administração e trabalhador". A expressão é incorreta. Não tratamos com dois grupos, "administração" e "trabalhador". mas com um mínimo de três:

- alta administração;

- administração média e

- o trabalhador.

Social e politicamente, os três grupos se diferenciam claramente. E a "comunicação" entre o grupo de administração média e o grupo de administração superior é tão difícil e geralmente tão inexistente quanto a comunicação entre qualquer um dos dois grupos e o de trabalhadores. O têrmo "comunicação" tende a assumir um significado puramente técnico na aplicação industrial. Refere-se mais aos meios de transmissão do que ao que é transmitido, mais ao telefone do que à conversação. Em consequiência, puramente técnico na aplicação industrial. Refere-se mais um problema técnico de pôr as informações ao alcance do trabalhador ou da administração. Mas não há escassez de meios técnicos; a maioria dos programas de "comunicação" - jornais da emprêsa, conferências de aperfeiçoamento, circulares aos empregados, inquéritos sôbre atitude dos empregados, etc. - duplicam os meios já existentes e as informações atuais já acessíveis a todos os grupos. $\mathrm{O}$ que falta é a vontade de cada grupo de ouvir, e a capaci-

$14 \quad$ Idem, ibidem, p. 199. 
dade para tanto, em outras palavras, falta mais compreensão e imaginação do que informações." "Essa falta de compreensão mútua reside na diferença de função entre os três grupos. Cada grupo vê a mesma coisa, a emprêsa, de um ponto de vista diferente. $O$ que um vê como fato óbvio e simples, o outro não o vê de modo algum. A alta administração vê o todo em têrmos de sua execução econômica, eficiência e produtividade, e como uma unidade numa economia complexa e competitiva. A administração média e a supervisão vêem a emprêsa como uma máquina complicada, como uma coleção de "departamentos" e de funções técnicas, e mais como auto-suficiente do que como uma unidade da economia. Mais comumente, não chegam a ver tanto; a visão de cada homem se limita à função técnica que ocupa. Êste é geralmente muito mais cônscio dos aspectos políticos e sociais da emprêsa do que a alta administração; e muito menos cônscio dos aspectos econômicos. Cada um dos membros da alta administração. sabe se a emprêsa está ou não indo bem, financeiramente. Poucos membros da administração média poderão, provàvelmente, dizer como anda a companhia, ainda menos ligar dados financeiros ao próprio trabalho. $O$ trabalhador é incapaz de ver qualquer dessas duas facêtas. Da posição em que se encontra, nenhuma função de administração tem muita significação; nem a alta administração, com sua atenção dirigida sôbre a responsabilidade econômica, e nem a administração média, com a sua dirigida para as funções técnicas e para a emprêsa como organização. 0 que determina a visão do trabalhador é sua relação para com o emprêgo e para com seus companheiros de traballıo. Mesmo se êle sabe o que se passa em outros setores da fábrica, êle não pode juntar êsses setores para chegar a. uma compreensão do conjunto da fábrica, ainda menos acrescentar a isso as funções invisíveis: venda e compra, engenharia e pesquisa, financiamento, ou o planejamento para o futuro, o que constitui a maior responsabilidade. 
da alta administração. Entretanto, embora o trabaihador veja apenas uma facêta, esta the parece ser o conjunto." ${ }^{15}$ A segunda importante contribuição de $A$ Nova Sociedade consiste na análise da função da gerência, a qual se caracteriza por três responsabilidades principais:

- responsabilidade pela sobrevivência da emprêsa na economia, isto é, pela lucratividade, seu mercado e seu produto;

- responsabiildade pela organização dos recursos humanos da emprêsa e pelo seu uso eficiente;

- responsabilidade por uma sucessão adequada para a alta administração.

Da defesa da sobrevivência da emprêsa, o gerente deve decidir qual é a natureza de seu negócio, isto é, em que negócio a emprêsa está realmente empenhada. A segunda responsabilidade é a organização e eficiente utilização dos recursos humanos. Uma organização ineficiente do comando provoca, inevitàvelmente, atrito, insatisfação e improdutividade, do alto para baixo. $O$ problema da sucessão da gerência é uma questão importante: "A administração tem que prover a sua própria sucessão. Como todos os corpos administrativos, a administração é bàsicamente autoperpetuante. $\hat{E}$ a administração de amanhã que determinará se a emprêsa irá prosperar dez anos mais tarde e até se a mesma irá sobreviver. Nem mesmo a administração mais capaz pode predizer o futuro. Até mesmo as melhores decisões tomadas hoje, com relação ao futuro, são forçosamente conjeturas. Mas a administração de hoje pode pelo menos certificar-se de que, para tomar as decisões de amanhã, haverá homens inteiramente capazes, inteiramente treinados e experimentados na execução prática" ${ }^{16}$ A grande estabilidade histórica do princípio da monarquia hereditária se deve precisamente à solução do problema da sucessão.

15 Idem, ibidem, p. 207 e 208.

16 Idem, ibidem, p. 226. 
Por outro lado, nenhuma instituição pode depender, para a sua sobrevivência, de um suprimento de gênios. Qualquer instituição deve ser organizada de modo que homens de capacidade pouco acima da comum possam dirigi-la, pelo menos em tempos normais. Mas, ao mesmo tempo, nenhuma instituição pode confiar à sorte a qualidade de sua chefia. Deve tentar selecionar os melhores homens de que dispõe para a sucessão, treiná-los e experimentá-los. A maioria das emprêsas ainda se encontra no estado primitivo de tribo, onde a sucessão atende a razões de idade ou de mágica. Vejamos, por exemplo, como se forma hoje o dirigente de uma emprêsa.

"O início do desenvolvimento de um chefe na emprêsa focaliza qualidades $\mathrm{e}$ habilidades que incapacitam um homem para um cargo de alta administração. Durante êsses primeiros anos, dá-se grande prioridade à maior especialização. A tecnologia da produção em massa requer que um homem se torne cada vez mais eficiente num setor cada vez mais reduzido, à medida que êle progride. Além disso, a emprêsa, quer grande, quer pequena, incita à departamentalização mental. Não é de praxe demonstrar curiosidade por outra função ou por outro departamento. Isso é, em parte, conseqüência de sua situação política normal e saudável, segundo a qual os departamentos e as funções competem entre si por maiores verbas e maior prestígio. Mas é também um subproduto ocasional do princípio de que cada chefe tem uma função claramente definida, pela qual só êle é responsável. $O$ resultado, entretanto, é que um homem que mostre demasiado interêsse pela emprêsa como conjunto, e que tente obter uma visão geral, terá pouca probabilidade de ser promovido. Além do mais, todo cargo de operação é, por natureza, circunscrito, quando não subordinado. $O$ que vale num chefe de operação é sua capacidade de cumprir as obrigações que lhe são designadas. Nem se espera nem se permite que êle seja independente - se é que o consultam, de algum modo, na elaboração das diretrizes que êle tem que executar. Nesses casos, o que importa é fazer coisas; o chefe 
de operações é treinado para ação rápida. É treinado para dar resultados imediatos e para exigir resultados imediatos dos seus subordinados. Espera-se que êle tenha as respostas para tôdas as perguntas acêrca de sua própria função e de seu próprio cargo. $\mathrm{E}$ - pior ainda - êle é treinado para concentrar-se inteiramente em "dados" concretos e precisos e não admitir quaisquer outros "fatos". Mas a tarefa da alta administração requer uma compreensão geral. Requer uma visão de conjunto. Exige capacidade comprovada de comando independente e a vontade de assumir a responsabilidade por uma decisão. Necessita de desprendimento, paciência e capacidade de longa visão. O homem do alto tem mais que pensar do que fazer; a sua atitude é mais de indagação do que de pronta aceitação de ordens. Enquanto o chefe de operações mede a sua tarefa em têrmos de números - de quantas toneladas de aço foram produzidas ontem - o alto administrador tem de pensar nos fatôres que influenciarão o consumo do aço nos próximos dez anos. A tarefa da alta administração nada tem da confortável certeza dos "dados" dos chefes de operações; quando muito, a alta administração trata com grandezas aproximadas mais comumente, porém, trata de coisas intangíveis, como tendências e suposições". ${ }^{17}$

Outro aspecto patológico da direção das emprêsas é seu isolamento e miopia social. "O grupo administrativo de qualquer grande organização vive em profundo isolamento social. Geralmente é jogado cada vez mais em contato com gente de sua própria condição social do mesmo negócio, quando não limitado à companhia do seu próprio grupo da alta administração. Isso conduz a um encolhimento da imaginação e da compreensão, cujo melhor exemplo talvez seja a incapacidade da administração norte-americana, nos últimos vinte anos, de compreender o povo estadunidense. As decisões da administração tendem, assim, a cair no vácuo". ${ }^{18}$

17 Idem, ibidem, p. 230.

Is Idem, ibidem, p. 232. 
Voltando ao problema da sucessão, no capítulo: "De onde virão os administradores de amanhã?", DRUCKER aponta algumas diretrizes comuns:

- crescente dependência do pessoal de staff como reservatório para a sucessão;

- o risco de basear-se no "príncipe herdeiro" e

- a impropriedade do critério de tempo de serviço.

A primeira diretriz baseia-se na visão de conjunto que o homem de staff geralmente obteve, mas o seu ponto fraco está na falta de experiência operacional.

Sôbre os príncipes herdeiros: "Pouco mais satisfatória é a tentativa de proporcionar treinamento especial e uma especial escada de promoção para uns poucos "príncipes herdeiros" escolhidos a dedo. Cada vez mais os jovens estão sendo promovidos a cargos de alta administração. Êsses jovens não são, como acontecia há cinqüenta anos, filhos ou parentes do dono, nem do pessoal da alta administração; qualquer coisa que cheire a "afilhadismo" encontra hoje a maior reprovação. Os jovens que tomaram o lugar do filho do dono de ontem são geralmente brilhantes diplomados de universidades, que foram escolhidos para uma rápida carreira no momento que entraram a serviço da companhia. Para os de fora, parecerá que êsses homens têm de galgar os mesmos degraus que qualquer outra pessoa. Começam como escriturários ou engenheiros aprendizes, seguem os degraus usuais. $\mathrm{Na}$ realidade, essa aparência de carreira normal é uma ilusão, quando não uma mera concessão às conveniências. Em geral, o brilhante e jovem candidato nem passa o tempo suficiente em cargo algum para obter um treinamento completo. Passa apenas o tempo necessário para se familiarizar com a gíria de um departamento. Ao contrário do homem de escritório, o "príncipe herdeiro" é, em geral, experimentado integralmente em comandos independentes. Desde cedo, êle recebe missões e responsabilidades importantes; desde 
o princípio, o seu cargo é o de um futuro alto administrador em preparo, mais do que o cargo de um autêntico subordinado. Mas suas missões serão missões "especiais". Continua sendo um estranho que, provàvelmente, não aceitará a organização nem será por ela aceito. Essa tentativa de solucionar o problema de sucessão é menos racional do que a sucessão por herança, de cinqüenta anos atrás, que a moderna administração tão virtuosamente rejeita. Pelo menos o preparo especial e a promoção do filho do dono eram honestos e feitos às claras. Todos sabiam que o rapaz, mais cedo ou mais tarde, seria o herdeiro do cargo. $O$ "principe herdeiro, por direito de nascença" tinha um título que o habilitava à sucessão. Era do interêsse da organização que um homem, tão òbviamente destinado à mais alta posição, fôsse bem treinado, bem familiarizado com a organização e bem preparado. "O "príncipe herdeiro por seleção", entretanto, causa ressentimento a todos". ${ }^{19}$

E igualmente impróprio o critério de merecimento empregado pela Igreja ou pelo Exército: um conjunto de tempo de serviço e de adaptação a uma tradição codificada. Em ambas as instituições, a ênfase não é quanto à capacidade de inovação, mas quanto à capacidade de conformar-se com um padrão imutável de conduta e de personalidade, aperfeiçoado durante um longo período.

Como o leitor pôde ver, nesses trechos em que procurei concentrar as idéias do autor, o livro $A$ Nova Sociedade é uma obra fundamental. Mais se acentua a preocupação de DruCker pela integração e eficiência dos administradores.

\section{A PRATICA DA ADMINISTRAÇÃo}

Em 1954, saiu nos Estados Unidos o que se considera, hoje, a obra-prima de Peter F. DRUCKer, a Prática de Administração de Emprêsas. ${ }^{20} \mathrm{O}$ livro é muito complexo

Idem, ibidem, p. 236.

so Drucker, Peter, F., Prática de Administração de Emprêsa, Rio de Janeiro, tradução portuguêsa da Editôra Fundo de Cultura, 1962. 
para que êste artigo possa abranger todos os seus aspectos, por isso preferi analisar apenas um: a teoria da administração por objetivos. De fato, esta foi a principal contribuição dêsse livro à ciência da administração. A administração por objetivos é um método de planejamento e contrôle administrativo, baseado na premissa de que para atingir resultados a emprêsa precisa definir em que negócio está e onde pretende chegar. Os objetivos anuais de emprêsa são feitos à luz de um plano de objetivos a longo prazo (quinquienais ou decenais), e os objetivos de cada gerente são feitos à luz dos objetivos anuais da emprêsa. Com isso, consegue-se uma firmeza de propósito que elimina as hesitações tão próprias das administrações atuais e consegue-se também uma coesão de fôrças em tôrno dos postos chave. "O desempenho esperado de um gerente deve ser reflexo do que se espera quanto à realização dos objetivos da emprêsa; seus resultados devem ser medidos pela contribuição que dêem para o êxito do negócio. $O$ administrador tem de saber e entender o que as metas da emprêsa esperam dêle em têrmos de desempenho, e o seu superior deve saber que contribuição poce exigir e esperar dêle e deve julgá-lo de conformidade com a mesma".

Numa emprêsa, o desempenho executivo não é automàticamente dirigido para o objetivo comum. Muito pelo contrário. Um negócio, pela própria natureza, contém tres poderosos fatôres de má orientação que estão no trabalho especializado da maioria dos gerentes, na estrutura hierárquica da administração e nas diferenças de visão, r.om o conseqüente isolamento de vários níveis de administração. Há sempre o perigo de que o verdadeiro profissional acredite que está realizando alguma coisa, quando, de fato. está apenas polindo pedras ou coligindo informações. A habilidade deve ser estimulada em qualquer emprêsa. Mas deve sempre estar em relação com as necessidades do conjunto. 
Deve ser estimulado o esfôrço do administrador no sentido de executar "perfeita administração de pessoal", de dirigir "a mais moderna de tôdas as fábricas", de fazer "pesquisa de mercado verdadeiramente científica", de adotar "o mais moderno sistema contábil" ou de conseguir "perfeita engenharia". Mas êste esfôrço pela eficiência profissional no trabalho funcional e especializado constitui também um perigo, pois tende a dirigir a visão e os esforços de um homem para longe dos objetivos da emprêsa. $O$ trabalho funcional torna-se um fim em si. Numa excessiva quantidade de exemplos, o administrador funcional já não mede o próprio desempenho pela contribuição que dê para a emprêsa, mas apenas pelo seu próprio critério profissional de eficiência. O desejo legítimo do administrador funcional de conseguir eficiência transforma-se, a menos que seja contrabalançado, numa fôrça centrífuga que esfacela a emprêsa e a converte numa relaxada confederação de impérios funcionais, cada um preocupado apenas com a própra função, cada qual guardando ciumentamente os próprios "segredos", cada um dedicado a ampliar o próprio domínio ao invés de consolidar a emprêsa.

Uma administração eficiente deve orientar a visão e os esforços de todos os gerentes para o objetivo comum. Deve estar certa de que o executivo individual compreenda quais resultados dêle se exigem. Deve garantir que o superior compreenda o que esperar de cada um dos gerentes que the são subordinados. Deve motivar cada chefe para o máximo esfôrço na direção correta. E, embora estimulando os mais altos padrões de eficiência, deve fazer dêles os meios para atingir os fins, que são as realizações da emprêsa, e não que constituam fins em si.

DRUCKER indica, em seguida, algumas das características dos objetivos para gerentes:

- os objetivos precisam ser claramente definidos, específicos, concretos. Não se excluem, é claro, certas declarações de objetivos intangíveis e genéricas, sempre que venham a ajudar a esclarecer; 
- os objetivos dos gerentes devem originar-se dos objetivos da emprêsa;

- nos objetivos deve ser dada ênfase ao trabalho de equipe e ao resultado global;

- os objetivos devem ser ajustados às considerações de curto e de longo alcance.

Algumas emprêsas enganam-se quando pretendem administrar por campanhas ou por crises, provocando um desequilíbrio nos esforços dos gerentes. Em algumas emprêsas, parece que só a campanha consegue mobilizar a gerência do torpor da rotina. Mas todos sabem que as coisas sempre voltam ao que eram antes, três semanas depois de encerrada a campanha. $O$ único resultado de uma "campanha de economia" quase sempre é a demissão de alguns mensageiros e datilógrafas, passando alguns executivos de salários elevados a datilografar suas próprias cartas, que podem ser batidas por alguém de salário baixo. $\mathrm{E}$ assim mesmo, muitas administrações não chegaram ainda à conclusão óbvia de que, afinal, não é por meio de campanhas que se consegue fazer as coisas. Mas, além e acima de sua ineficiência, a administração por campanhas tem o defeito de orientar no sentido errado, pondo tôda a ênfase numa fase do trabalho inevitàvelmente em detrimento de tudo o mais. Numa organização dirigida por campanhas, o pessoal negligencia obrigações, a fim de não ficar atrás na campanha em vigor, ou silenciosamente se organiza para a sabotagem coletiva da campanha em andamento, a fim de poder realizar seus encargos habituais. A maior de tôdas as vantagens da administração por obietivos é talvez a de possibilitar ao administrador o contrôle do próprio desempenho. Autocontrôle quer dizer mais forte motivação: o desejo de conseguir o máximo e não simplesmente de conseguir o bastante para ir vivendo. Significa metas mais elevadas e visão mais ampla. Mesmo que a administração por objetivos não fôsse necessária para dar à emprêsa a unidade de direção e do esfôrço de 
uma equipe administrativa, seria necessária para tornar possível a administração por autocontrôle.

Para que possa controlar o próprio desempenho, um administrador precisa saber mais do que simplesmente os seus objetivos. Deve ter condições de medir o próprio desempenho e os resultados obtidos em comparação com o objetivo. Deveria constituir, mesmo, prática invariável o fornecimento, a cada gerente, de unidades de medida claras e comuns a todos os setores-chaves de uma emprêsa. Estas unidades não precisam ser rìgidamente quantitativas; nem necessitam ser exatas. Mas têm de ser claras, simples e racionais. Têm de ser relevantes e de dirigir as atenções e os esforços para onde devem êles convergir.

A administração por autocontrôle impõe uma revisão completa no que diz respeito ao emprêgo de relatórios, normas e fórmulas. Relatórios e normas são instrumentos: podem ser fàcilmente mal empregados e causar dano. Há três maneiras de usar impròpriamente relatórios e normas. A primeira é a crença tão generalizada de que normas de ação são instrumentos de moralidade. Não o são, pois seu princípio é exclusivamente de economia. Outro emprêgo errado é considerarem-se as fórmulas como substituto do raciocínio. As fórmulas podem dar resultado apenas onde o raciocínio já não seja necessário, isto é, nas situações repetitivas para cuja solução o raciocínio já foi suprido e comprovado. Nossa civilização padece de uma fé supersticiosa no efeito mágico da fórmula impressa. $E$ a superstição torna-se ainda mais perigosa quando nos leva a tentar resolver a situação excepcional, fora da rotina, pela fórmula. De fato, a prova de uma boa fórmula é que ela identifica ràpidamente as situações que, mesmo no mais rotineiro dos processos, não se encaixam no padrão, exigindo tratamento especial. Porém, o mais comum dos maus empregos das fórmulas e relatórios é usá-los como instrumento de contrôle de cima para baixo. $O$ caso bem conhecido do gerente de fábrica que tem fe preencher vinte formulários para dar a contadores, engenheiros ou 
assessôres da matriz, informações de que êle próprio não precisa, é apenas um entre milhares de exemplos. Em conseqüência, a atenção dêste homem é desviada de suas obrigações. As coisas que lhe são perguntadas ou que é forçado a fazer para efeito de contrôle acabam sendo-lie apresentadas como reflexos do que a companhia dêle deseja, tornando-se assim na essência de seu serviço. Relatórios e fórmulas devem ser instrumentos de quem os preenche e não devem jamais se transformar em medida do seu desempenho. Um homem nunca deve ser julgado pela qualidade dos formulários de produção que lhe cabem preencher, a menos se trate do empregado encarregado dos formulários.

A administração por objetivos, compreendida como foi exposta, não é apenas um método de trabalho, mas pode ser uma filosofia da administração. Baseia-se no princípio de motivação do comportamento humano, aplica-se a todo administrador e assegura uma genuína liberdade ao executivo.

Um especial capítulo do livro é dedicado aos "Objetivos da Emprêsa". Êsse capítulo tornou-se um clássico da administração e vem sendo resumido e citado em muitas obras contemporâneas.

Há necessidade de objetivos em todo o setor da emprêsa em que a realização e os resultados afetem vitalmente a sobrevivência e a prosperidade do negócio. Êsses são os setores-chave. Objetivos nesses setores-chave permitem, entre outras coisas, predizer comportamentos avaliar a sensatez das decisões e analisar a experiência dos homens da emprêsa. São oito os setores-chave:

- Posição no mercado.

- Inovação.

- Produtividade.

- Resursos físicos e financeiros.

- Rentabilidade. 
- Desenvolvimento dos gerentes.

- Desempenho e desenvolvimentos dos empregados.

- Responsabilidade pública.

A posição no mercado tem de ser medida contra o potencial do mercado e contra o desempenho dos fornecedores de produtos e serviços concorrentes, seja a concorrência direta ou indireta. Por si, o volume de vendas diz pouco sôbre a realização, os resultados ou o futuro do negócio. As vendas de uma companhia podem subir - estando a firma, na realidade, destinada a breve colapso. Não sòmente os números absolutos de vendas pouco significam, por si só, uma vez que devem ser projetados contra as tendências reais e potenciais do mercado, como a própria posição no mercado tem importância intrínseca. Uma emprêsa que forneça menos que certa porção do mercado torna-se um fornecedor marginal; seus preços tornam-se dependentes das decisões dos grandes produtores.

A fim de poder estabelecer objetivos de posição no mercado, um negócio deve primeiro descobrir o que é seu verdadeiro mercado, quem é o cliente, onde está êle, o que compra, o que considera valor, quais suas necessidades insatisfeitas. Com base neste estudo, a emprêsa deve analisar seus produtos ou serviços, de acôrdo com "linhas", isto é, segundo as necessidades dos clientes que êles satisfaçam.

O autor aponta, em seguida, sete objetivos para comercialização:

- “A posição dos produtos existentes em seu mercado atual, expressa tanto em dinheiro quanto em percentagem do mercado e medida contra a concorrência, tanto direta como indireta".

- "A posição dos produtos existentes nos mercados novos, estabelecida tanto em dinheiro como em percentagem e medida contra a concorrência direta ou indireta." 
"Os produtos existentes que devem ser abandonados por motivos tecnológicos, em virtude das tendências do mercado para melhorar o complexo do produto ou em consequiência de decisões administrativas referentes ao que deve ser a base do negócio."

- "Os novos produtos necessitados nos mercados existentes - a quantidade de produtos, suas propriedades, o volume em dólares e a porção do mercado que devem abranger por si."

- "Os novos mercados que os novos produtos deverão criar - em dinheiro como em percentagem."

- "A organização distribuidora necessária para realizar os objetivos de marketing e a política de preços apropriada a tais objetivos."

- "Um objetivo de serviço destinado a medir até que ponto de excelência deve o consumidor ser servido naquilo que êle considere valor - pela companhia, por seus produtos, suas vendas e sua organização de serviço."

O segundo setor-chave para os objetivos é o da inovação. Há inovações que modificam o produto e inovações que modificam os processos para seu suprimento. A inovação pode originar-se de necessidades do mercado ou do consumidor; a necessidade pode ser a mãe da inovação. Ou pode resultar do trabalho de aperfeiçoamento da capacidade e do conhecimento, realizado em escolas e laboratórios. A dificuldade consiste na medição dos resultados possíveis. $O$ autor recomenda estas cinco metas de inovação:

Novos produtos ou serviços, necessários a que se alcancem os objetivos de marketing.

Novos produtos ou serviços que se tornarão necessários em face de mudanças tecnológicas capazes de tornar obsoletos os produtos atuais. 
Aperfeiçoamento nos produtos, necessários tanto para alcançar os objetivos de mercado como para antecipar mudanças tecnológicas esperadas.

Novos processos e aperfeiçoamentos de processos antigos, necessários para satisfazer metas de mercado por exemplo, aperfeiçoamentos de fabricação destinados a possibilitar o alcance de objetivos de preço.

Inovações e melhorias em todos os principais campos de atividade - em contabilidade ou desenho, em trabalhos de escritório ou relações trabalhistas - de maneira a manter a firma em dia com os progressos em matéria de conhecimento e habilidade.

"Muitas companhias devem a posição de liderança, que hoje desfrutam, à atividade de uma geração que labutou há vinte e cinco anos ou mais. Muitas companhias hoje desconhecidas do público liderarão amanhã seus ramos industriais em virtude de suas inovações de hoje. A emprêsa bem sucedida corre sempre o risco de estar vivendo à custa da energia inovadora acumulada uma geração atrás."

O terceiro setor-chave para objetivos é a produtividade. A medição da produtividade é uma avaliação da competência dos administradores porque permite a comparação entre as gerências das diferentes unidades de uma mesma emprêsa ou de emprêsas diferentes. Afinal de contas, os vários ramos de negócio têm mais ou menos os mesmos. recursos para explorar. A medição da produtividade indica quem melhor os utiliza.

Um quarto importante setor-chave para objetivos é o dos recursos físicos e financeiros. Dando diversos exemplos, o autor indica a necessidade de uma "administração de investimentos", de planos a longo prazo para o abastecimento futuro de recursos físicos e da importância do planejamento de instalações e equipamentos. Numa quantidade muito grande de companhias - inclusive algumas consideradas como muito bem dirigidas - as falhas no tocante à previsão de suprimento de capital e à fixação 
de objetivos de capital têm tolhido o crescimento e anulado muito trabalho brilhante de marketing, inovação e produtividade.

Para não me alongar nessas considerações chamo a atenção do leitor para os setores-chave seguintes:

- rentabilidade, desenvolvimento de gerência e de empregados e

- responsabilidade pública.

Os objetivos de rentabilidade podem, hoje em dia, ser melhor determinados graças à técnica da "análise do ponto de equilíbrio", que na época da publicação dêste livro era uma novidade. $O$ autor observa que, antes dessa descoberta, "o fato de os nossos administradores terem conseguido dirigir seus negócios até hoje sem uma política racional de investimentos constitui um feito de navegação tão espantoso quando o de LEIF ERICKSON, encontrando o caminho de volta de Vineland através do Atlântico, sem mapa, bússola ou sextante".

Finalmente, convém uma observação sôbre o equilíbrio dos objetivos: "Poucas coisas distinguem tão bem a administração competente da incompetente quanto o desempenho em matéria de equilíbrio de objetivos. Todavia, não existe uma fórmula para tal tarefa. Cada emprêsa exige um meio próprio - e pode haver necessidade de meios diferentes em diferentes períodos. $O$ máximo que se pode dizer é que equilibrar objetivos não é tarefa mecânica nem pode ser conseguido "orçamentando". $O$ orçamento é o documento no qual encontram sua expressão final as decisões destinadas a trazer êsse equilíbrio; as próprias decisões exigem critério e êste critério só será correto se baseado numa correta análise do negócio. $\mathrm{O}$ falecido Nicholas DReystadt, dirigente da Cadillac e um dos mais sensatos administradores que conheci, disse-me certa vez: "Qualquer tolo é capaz de se manter dentro de um orçamento, mas em tôda a minha vida só encontrei alguns administradores capazes de fazer um orçamento dentro do qual valha a pena a gente se manter". 
Poucos anos passaram após a Prática de Administração de Emprêsas e surgiu em 1959 uma nova obra de DRUCKER, intitulada Fronteiras do Amanhã. ${ }^{21}$ Para quem está familiarizado com as obras anteriores, êste livro parece um desvio de temática, de dentro para fora da organização. O foco central não é mais tornar a administração mais eficiente, mas apreciar algumas das mudanças sociais que estão correndo no mundo pós-moderno, tais como a inovação tecnológica, as novas características da organização de grande porte e a revolução educacional.

Segundo o próprio autor, o livro é uma obra incompleta que falhou em abranger tôda a vastidão do tema escolhido. Recentemente, DRUCKER revelou-me, numa entrevista, que está preparando um nôvo livro que é a continuação das Fronteiras. Tomada assim, esta obra é um desafio que o próprio autor se impôs, para tentar uma síntese do caudal de informações existentes sôbre o futuro mais próximo de nossa sociedade industrial.

$\mathrm{Na}$ primeira parte, o autor focaliza a nova visão de um mundo pós-moderno e pós-cartesiano, ainda em transição e sem feições definidas. Êsse mundo caracteriza-se pela inovação em ritmo vertiginoso e por um nôvo conceito de organização social. "Sem que o percebêssemos, durante os últimos vinte anos, saímos, num dado momento, da Idade Moderna e entramos numa nova era, ainda sem denominação. Nossa visão do mundo mudou; adquirimos uma nova consciência e, com ela, novas capacidades. Existem agora oportunidades, riscos e desafios, bem como um nôvo centro espiritual da existência humana".

$\mathrm{Na}$ segunda parte, apresenta algumas características dêsse amanhã mais próximo: a sociedade culta, a exigência pelo

21 DRUCKER, Peter F., Landmarks of Tomorrow. Tradução portuguêsa: Fronteiras do Amanhã, Rio de Janeiro, Editôra Fundo de Cultura, 1964. Entre essas duas obras, o autor publicou em $1957 \mathrm{um}$ livro de ensaios, The Next Twenty Years, que se refere especificamente à condição americana e que aqui não comentarei. 
desenvolvimento econômico, e o eclipse das civilizações clássicas como as orientais.

Na terceira parte, o autor esboça um quadro da atual situação humana, em que tanto o poder como a ciência tornaram-se absolutos e adquiriram a capacidade da destruição absoluta. Pela primeira vez, desde o início da civilização, o homem é forçado a pensar na natureza e no contrôle do poder e da ciência.

Como venho fazendo na análise das obras anteriores, prefiro destacar neste livro alguns temas fundamentais mesmo que com o sacrifício de outros. Um dêsses temas é o da inovação. Houve em nossa época uma verdadeira explosão da pesquisa científica. Para o seu desenvolvimento, a emprêsa comercial e a organização de pesquisa adquiriram importância capital. Mesmo as velhas instituições, como o exército e a escola, estão deixando de ser preservadores de tradição para passarem a órgãos de inovação. Nos últimos trinta anos, as despesas com pesquisa tecnológica na indústria americana elevaram-se cêrca de setenta vêzes mais. Uma grande companhia holandesa, a Philips, aumentou cinqüenta vêzes as suas pesquisas apesar da depressão, da guerra e da ocupação inimiga.

"Uma ilustração do impacto da inovação nas adaptações do presente conhecimerto é o desenvolvimento de uma teoria da mudança de uma economia subdesenvolvida pré-industrial e estática para uma progressiva, avançada e industrializada. Há dez anos atrás, não existia uma teoria semelhante. Hoje temos uma teoria realmente rude e primitiva, mas bastante adequada para merecer a aceitação geral dos economistas, não obstante a diversidade de suas opiniões e de onde trabalham, dentro ou fora dos países socialistas. À diferença de tôdas as outras importantes teorias econômicas, não existe um só economista a cujo nome possa ser creditada a teoria do desenvolvimento econômico. 
Foi axiomático para os economistas tradicionais, inclusive para MARX, que os recursos disponíveis determinam o que pode ser produzido e, reciprocamente, que os produtos existentes requerem recursos específicos. Essa é a expressão econômica característica do ponto de vista cartesiano: se tivermos aço existirão certas coisas que poderemos produzir. Essa visão determinista está mudando ràpidamente sob o impacto da inovação. Podemos já decidir, de modo sempre crescente, de que produtos manufaturados necessitamos e então descobrir as matérias-primas para êles. É mais acertado, hoje em dia, para um país, para um técnico, ou para um negócio, iniciar com a suposição de que não existem limitações, do que começar com a camisade-fôrça determinista da tradição e do conhecimento existentes". ${ }^{22}$ "A idéia tradicional de uma melhor distribuição de recursos está sendo substituída pela escolha entre as condições mais favoráveis, que são mais o resultado de ações e decisões puramente humanas do que pròpriamente dos recursos dados por Deus". ${ }^{23}$

A inovação traz consigo três riscos:

- o risco de ser surpreendido pela inovação;

- o risco do malôgro da inovação e

- o maior de todos, o risco do êxito da inovação.

Sôbre êste último, diz o autor: "Os riscos da exposição e do fracasso são pequenos se comparados ao terceiro: o do êxito da inovação. Que impacto terá uma inovação bemsucedida além do que é desejado? Que novas e inesperadas mudanças irá ela produzir? Que influência irá ter sôbre a estrutura social, sôbre suas crenças e seus laços comunitários?" A inovação não é sòmente oportunidade, é acima de tudo responsabilidade. Ninguém é responsável pela sorte; ninguém pode fazer algo a êsse respeito. Podemos apenas bendizer o progresso inevitável, ou lamentá-lo;

Idem, ibidem, p. 42.

Idem, ibidem. p. 43. 
podemos, no máximo, tentar retardá-lo. Mas a inovação é escolhida deliberada e assim somos responsáveis pelas suas conseqüências. A inovação é, conseqüentemente, sempre de natureza ética - tanto quanto ela é um processo intelectual e uma percepção estética.

Passemos agora ao segundo tema importante do livro: a nova organização. Um grande número de obras de ficção e de ensaios têm sido escritos sôbre o poder nas grandes organizações. Na Inglaterra, um autor, C. P. SNOw, ${ }^{24}$ notabilizou-se pelos ensaios sôbre a responsabilidade da pesquisa tecnológica e sôbre o comportamento de homens que trabalham juntos nas grandes organizações.

$\mathrm{Na}$ nova organização aparecem agora $\circ$ administrador profissional, o cientista de alto nível e um nôvo estilo de organizar o esfôrço humano. Em virtude disto, a emprêsa industrial aparece como a instituição central de nossa sociedade. Essa posição-chave da emprêsa na revolução da organização explica porque as instituições mais velhas, como as fôrças armadas, o govêrno e até a Igreja Católica, olham-na como modêlo de organização e procuram aplicar alguns de seus novos princípios de organização.

A automação pode eliminar o trabalhador incompetente do plano da produção. Mas o substitui por um igual número de homens de alto talento e raciocínio. Cada um dêles trabalha em seu próprio campo de conhecimento com uma larga área de julgamento e, não obstante, deve trabalhar com todos os outros - em constante comunicação com êles, ajustando-se às suas decisões e, por sua vez, tomando decisões que afetam seus trabalhos. A nova organização está transformando o trabalho, antigamente confinado ao esfôrço individual. Ela não substitui 0 indivíduo pela organização, mas torna-o mais efetivo no trabalho conjunto.

No exército, a especialização funcional está gradualmente cedendo lugar à integração interfuncional, por exemplo.

2 C. P. Snow, The Masters e The New Men 
na Equipe Regimental de Combate. Mesmo na universidade - a mais especializada de tôdas as nossas organizações, e a única onde, como de regra, os departamentos e linhas de especialidade são rìgidamente traçados - os cursos e pesquisas interdisciplinares estão se tornando cada vez mais comuns. Ali, inúmeros estudiosos de diferentes disciplinas trabalham juntos numa matéria de interêsse comum para a qual cada um dêles contribui com seu próprio conhecimento. Hoje em dia, temos a clínica diagnóstica em que os especialistas trabalham juntos em equipe - no paciente que é antes uma unidade do que um campo de conhecimento especializado. De maneira crescente, profissionais não médicos estão tomando parte no grupo: dietéticos, psicólogos, assistentes suciais, sociólogos, terapeutas.

Dentro da nova organização, o administrador profissional aparece como o agente do desenvolvimento e da coordenação. Ao antigo magnata, de grande fortuna e hábil manipulação financeira, sucede, no tôpo das grandes organizações, o administrador com a característica de organizar o esfôrço humano.

A grande organização proporciona oportunidades sem precedentes para a promoção, mais do que qualquer estrutura social do passado. Por outro lado, a competição que ela estimula tem criado tensão e desgaste em muitos administradores.

Passemos agora ao exame de um terceiro tema do livro: a sociedade culta. São sintomas de uma sociedade que tem fé na educação: o aumento em número e tamanho das universidades, a extensão do tempo em que uma pessoa passa realizando estudos pós-graduados, o aumento da idade média em que a pessoa inicia sua vida profissional, o aumento das exigências quanto a qualificações para determinado trabalho.

"Para ser uma pessoa eficiente numa sociedade educada, qualquer um, não importa qual seja o seu trabalho, pre- 
cisa de certa formação. Faz-se necessário conhecer o homem, sua grandeza e sua miséria, sua personalidade, sua história e sua sociedade. Êle precisa de uma base no conhecimento de pesquisa sistemática que chamamos de ciência - seus métodos, sua história, suas hipóteses fundamentais e suas principais teorias. Precisa de um mínimo de competência no uso da habilidade de imaginar, analisar, formular, interpretar e transmitir aquilo que chamamos de linguagem e que inclui, naturalmente, a matemática; da habilidade de imaginar, compreender, formular, interpretar e transmitir a experiência que chamamos de artes; de ser capaz de esforçar-se para distinguir-se num determinado campo. Isso significa especialização, uma vez que ninguém pode alcançar a perfeição senão num campo limitado. Isso significa educação para a contribuição em ação, que é a educação prática. A habilidade especializada torna-se sobretudo efetiva numa ocupação profissional e por meio dela dentro da nova organização. Não obstante, o profissional só é eficiente, isto é, prático, numa organização, se sabe bastante acêrca do universo do saber para referir-se a si próprio e ao seu trabalho. Para ser eficiente, êle deve, por conseguinte, ter uma base de cultura geral e ser capaz de manejar os instrumentos do pensamento e da experiência que são universais em vez de especializados". ${ }^{25}$

Se, por um lado, o aumento do tempo de permanência na escola é sintoma de maior exigência educacional de nossa sociedade, por outro, essa extensão temporal é ilusória. IJão há nenhuma vantagem em aumentar os anos, se não aumentar a organização escolar. $O$ problema está em fazer cada ano mais eficiente. Não devemos nos bater por um trabalho mais rigoroso, mas por um trabalho mais intenso. $\mathrm{O}$ terceiro aspecto da educação é sua responsabilidade. A sociedade deve exigir que a educação seja considerada pelo educando mais como uma responsabilidade do que como um direito. $\mathrm{O}$ acadêmico deve perguntar: "Como

20 DRUCKER, Peter F., Fronteiras do Amanhã, p. 128 e 129. 
posso contribuir?" antes de "Que vantagem tenho nisso"? A explosão educacional ocorre numa era em que o saber vai se transformando numa ameaça e o seu contrôle num problema metafísico. Nos próximos vinte anos, a duplicação ou triplicação da matrícula universitária suscitará, por si mesma, problemas sociais desnorteantes. A "cultura do acadêmico" poderá tornar-se a cultura de massa do futuro.

O autor conclui o livro com a visão da grandeza e do desafio dos próximos anos e com a visão retrospectiva do passado que se distancia ràpidamente. "O estudo sôbre 0 mundo pós-moderno está finalmente concluído. Ėle decorreu, ora de modo otimista, senão de entusiasmo, ora de modo melancólico, senão de desalento. Pois o mundo pós-moderno é uma era de transição, uma idade de expectativa, prenhe de desafios e de oportunidades alentadoras; prenhe também de terríveis e temerosos perigos; uma idade que reúne, inseparàvelmente, $\mathrm{o}$ encanto $\mathrm{e} o$ terror do desconhecido, o impacto de novas ações a serem realizadas $\mathrm{e}$ as penalidades das antigas omissões a serem julgadas. Estamos hoje no meio de um rio. A maioria de nós ainda toma o velho mundo como seguro. Mas uma coisa é certa: o passado se distancia ràpidamente".

\section{ADMINISTRAÇÃO PARA RESULTADOS}

Em 1964, DRUCKer publicou Managing for Results, ${ }^{26}$ que, após Fronteiras do Amanhã, constitui uma volta a temas da Prática de Administração de Emprêsas. Uma volta certamente mais esclarecedora e com algumas idéias de profunda originalidade avançando sôbre as posições anteriores. $\mathrm{O}$ tema principal de DRUCKER - a eficiência dos administradores - volta a aparecer e sofre agora novos tratamentos. Managing for Results é uma obra ca-

\footnotetext{
28 DRUCKER, Peter F., Managing for Results, Nova Iorque, Harper \& Row, Publishers, 1964. Traduzido com o título Administração para Resultados, Rio de Janeiro, Zahar Editôres, 1968.
} 
pital, referida já em diversos livros estrangeiros; ela deixará algumas notáveis contribuições como a classificação mercadológica de que tratarei mais adiante.

$\mathrm{O}$ que interessa à emprêsa não é trabalho mas resultados. "O trabalho atual do executivo toma todo o seu tempo; e, apesar disso, raramente é bem feito. Poucos gerentes estão bem impressionados com seu próprio desempenho nas tarefas imediatas. Êles se sentem tomados por uma "corrida de ratos" e manejados por qualquer coisa que o mensageiro coloca em sua caixa de "entrada". ${ }^{27} \mathrm{O}$ executivo cônscio de resultados precisa substituir o executivo preocupado em trabalhar. Para isso a emprêsa necessita introduzir um sistema econômico de planejamento e avaliação mercadológica que the permita substituir o enfoque do trabalho pelo dos resultados. "A verdadeira doença é a falta de qualquer base de conhecimentos e sistema para lidar com as tarefas econômicas dos negócios."

A tarefa econômica da emprêsa tem três dimensões:

- o presente trabalho precisa ser mais eficiente;

- seu potencial deve ser identificado e realizado;

- êle precisa ser transformado num negócio diferente, tendo em vista um futuro diferente. 0 futuro não será feito amanhã. Está sendo feito hoje, em grande parte pelas decisões e ações tomadas com respeito às tarefas de hoje. No início do livro o autor aponta algumas das suposições básicas que o orientam:

- Dentro do negócio não há resultados nem recursos. Ambos existem fora. Não há centros de lucro dentro do negócio, apenas centros de custo. As oportunidades de uma emprêsa residem fora dela, no ambiente em que está.

- Os resultados são obtidos pela exploração das oportunidades, não apenas pela solução dos problemas. Tudo o que se pode esperar, quando se resolve um problema, é

27 Idem, ibidem, p. 31 . 
restaurar a normalidade. $O$ enfoque do executivo moderno não deve ser o de resolver problemas, mas de explorar as oportunidades que surgem.

Os recursos precisam ser concentrados nas oportunidades, não nos velhos problemas. Muitas emprêsas dispersam seus recursos financeiros, empatando-os em produtos problemáticos, de rentabilidade duvidosa.

Os resultados econômicos são ganhos sòmente pela liderança, não pela mera competência. Os lucros são as recompensas da liderança, isto é, faz lucros a emprêsa que dá uma especial e distinta contribuição numa área significativa. As mais importantes organizações de hoje devem o seu sucesso à inovação e à liderança num determinado ramo.

- Tôda situação de liderança é transitória e de vida curta. Nenhum negócio está seguro em sua posição de liderança. $O$ que era líder ontem, hoje possivelmente não o mais é. E, assim, as emprêsas que hoje lideram devem inquietar-se com a continuidade de sua posição.

- O que existe está ficando velho. Dizer que muitos executivos gastam a maior parte de seu tempo resolvendo os problemas de hoje é um eufemismo. Êles gastam a maior parte do tempo sôbre problemas de ontem. É sempre fútil restaurar a normalidade; a "normalidade" é apenas a realidade de ontem.

- Provàvelmente o que existe está mal alocado. Enquanto $90 \%$ dos resultados são produzidos pelos primeiros $10 \%$ dos eventos, $90 \%$ dos custos são feitos pelos restartes $90 \%$ de eventos sem resultados. Os recursos são geralmente alocados em $90 \%$ de eventos que não dão resultados.

A concentração é a chave dos resultados econômicos: concentrar recursos no pequeno número de produtos e 
atividades que produzem maior rendimento. $O$ reverso é o abandono. $\mathrm{O}$ abandono corajoso de produtos não-rentáveis é uma chave do sucesso da emprêsa.

Colocadas essas suposições como as hipóteses fundamentais do livro, DRUCKER parte para a análise dos resultadoschave da companhia. Nesse momento, a "técnica do desacôrdo" é bastante necessária. "A análise dos resuitados-chave da companhia deve levar à discussão e dissenção. E importante obter desacordos porque êles trazem mais luz sôbre os produtos, políticas e direção. Nada é mais perigoso nos assuntos de importância e impacto do que uma decisão por aclamação. $O$ acento nesta fase do trabalho consiste em tirar fora as áreas de desacôrdo em vez de conseguir uma perfeição técnica na análise. $O$ que precisa ser conseguido não são "respostas certas", mas "perguntas certas". ${ }^{28}$

Aqui entra a avaliação mercadológica que DRUCKER propõe. Êle observa que de cada 100 novos produtos:

- 1 é um sucesso real;

- 19 são fracassos rápidos e menores e

- 1 é fracasso espetacular.

Ocorre que os produtos que são fracassos espetaculares e fracassos rápidos são abandonados pela própria necessidade, quando não permanecem como investimento emocional de algum diretor. Mas a grande parte é constituída por aquêles produtos que, por não parecerem fracasso e servirem de absorvedores das "despesas gerais", a gerência não tem a coragem de abandonar. Nesses produtos, costuma-se dissolver tôda a disponibilidade financeira da emprêsa, como se o investimento de dinheiro pudesse torná-los mais rentáveis.

Idem, ibidem, p. 16. 
A fim de estabelecer critérios para a avaliação mercadológica dos produtós, DRUCKER propõe a lista de categorias seguinte:

- O ganha-pão de hoje.

- O ganha-pão de amanhã.

- As especialidades produtivas.

- Os produtos em desenvolvimento.

- Os fracassos.

- O ganha-pão de ontem.

- As funções de reparo.

- As especialidades desnecessárias.

- As especialidades injustificadas.

- Os investimentos na vaidade gerencial.

- As cinderelas ou produtos que estão dormindo.

Vejamos em que consistem êsses têrmos. Ganha-pão de hoje é aquela classe de produtos que têm um volume substancial e boa margem líquida. Esses produtos, geralmente, são amplamente apoiados por recursos até mais do que sua margem de lucro justifica.

Ganha-pão de amanhã é o produto que ainda está em desenvolvimento e que, pelo planejamento da emprêsa, terá, no futuro, uma boa margem líquida e grande volume. Especialidades produtivas são os derivados dos produtos principais que oferecem boa vantagem.

Produtos em desenvolvimento: deve-se evitar que êles se tornem investimentos da vaidade gerencial e, portanto, futuros fracassos.

Ganha-pão de ontem é o produto que dava lucro no passado e que ainda é mantido na esperança de que volte a fazê-lo; êste é geralmente um produto que consome os recursos da emprêsa e deveria ser abandonado; costuma ter grande volume de vendas, lucro bruto pequeno em 
relação a êsse volume; enfim, tôdas as pessoas de dentro da emprêsa gostam do velho produto que ajudou a construir a companhia.

Funções de reparo são produtos ou serviços de assistência cujo custo é justificado apenas pelo lucro do ganha-pão de hoje.

Investimentos na vaidade gerencial são aquela classe de produtos que se comercializam apenas para apagar o amor próprio do diretor que os fêz desenvolver; em geral, os dirigentes investiram tanto nesses produtos por uma questão de orgulho que agora se recusam a enfrentar a verdade; quanto mais o produto falha em atender às expectativas, mais a gerência se liga a êle e mais recursos são bombeados para ajudá-lo.

Cinderelas ou sleepers são os produtos que dormem quando poderiam ser despertados para o sucesso comercial.

Prosseguindo na análise do que chama de "realidades mercadológicas", o autor aponta outras suposições:

- O que as pessoas do negócio pensam que sabem do consumidor e do mercado é provàvelmente mais errado. do que certo.

- O consumidor raramente compra o que a companhia pensa que the vende.

- Os bens e serviços que o produtor pensa que são competidores diretos provàvelmente não o são.

- O que o produtor pensa ser o aspecto mais importante do produto para o consumidor provàvelmente é menos importante.

- Presume-se que o consumidor seja racional, mas a sua racionalidade não é necessàriamente a mesma que a do fabricante.

- Nenhum produto ou companhia em separado é importante para o mercado. $O$ consumidor liga pouco para uma só companhia ou produto. 
Estas hipóteses levantadas por DRUCKER podem ser em seguida experimentadas através de algumas perguntas que a interpretação dos dados irá responder: Quem é o nãoconsumidor (o que não compra nossos produtos apesar de estar no mercado)? Por que êle não é nosso consumidor? $O$ que o cliente compra além do nosso produto? $O$ que êle faz com seu dinheiro e seu tempo? $O$ que os clientes e não clientes compram dos outros? Que satisfações obtêm com isso? Que produto ou serviço preencheria as áreas de satisfação importantes — tanto as que servimos como as que não servimos? $O$ que fariam os clientes sem o nosso produto? Quais são os acessórios significativos?

Como conseqüência da análise dessas "realidades mercadológicas", a emprêsa deve avaliar o capital formado pelos seus conhecimentos. Ver as coisas que fêz bem e as que fêz pobremente. Perguntar: qual é nosso negócio? O que estamos em condições de fazer bem? "O conhecimento é um bem perecivel. Êle precisa ser reafirmado, reaprendido, repraticado todo o tempo. Uma pessoa precisa trabalhar constantemente para reconquistar a própria liderança específica. Todo conhecimento torna-se conhecimento errado. Torna-se absoluto. A pergunta deveria ser: Do que mais precisamos? Ou, precisamos de algo diferente?" ${ }^{29}$

Nenhuma emprêsa pode tornar-se excelente em muitas áreas de conhecimento, por isso a emprêsa deve concentrar-se em fazer poucas coisas muito bem. De cada 100 negócios que começam, 75 morrem antes de seu quinto aniversário, com o fracasso da administração como causa principal.

No exame dos seus conhecimentos técnicos, a emprêsa pode formular estas perguntas:

Temos o conhecimento certo?

- Estamos concentrados onde estão os resultados?

Idem, ibidem, p. 117. 
- Estamos sendo pagos pelo conhecimento com que contribuímos?

- Nosso conhecimento está adequadamente aplicado em nossos bens e serviços?

- Como podemos melhorar?

- O que estamos perdendo?

Para dar resultados, a administração não deve temer as decisões de abandono dos produtos não rentáveis. "O abandono é a chave da inovação, não só porque êle liberta os recursos necessários, mas porque êle estimula a procura do nôvo que substituirá o velho." ${ }^{30}$ Os custos escondidos de qualquer atividade são muito maiores do que uma pessoa pode supor ou do que os sistemas de contabilidade mostram. A General Motors abandonou seis entre oito produtos que estavam em linha de produção e o resultado foi o crescimento da emprêsa.

$\mathrm{Na}$ busca de novas oportunidades tôda emprêsa deve estar aberta para o futuro. Sabem-se duas coisas sôbre o futuro: que não pode ser conhecido e que será diferente de hoje. Analisar o futuro significa analisar os eventos significativos de hoje quanto ao seu impacto no amanhã. Os grandes eventos têm sempre um espaço de tempo entre si e seu impacto, nas pessoas e nas idéias. Duas fontes importantes de investigação são, sem dúvida, a população: (as maiores mudanças de mercado foram criadas pelas mudanças de população) e o tempo de lazer que leva à procura de novos bens e conhecimentos. Pode-se perguntar:

Aconteceu alguma coisa que poderá estabelecer uma nova realidade para a indústria, o país, o mercado?

Está acontecendo alguma coisa na estrutura de uma indústria que indica uma mudança maior?

Idem, ibidem, p. 143. 
- Quais são nossas suposições básicas sôbre a sociedade e a economia, o mercado e o consumidor, o conhecimento e a tecnologia?

\section{Elas ainda são válidas?}

Como se vê, Managing for Results representa um passo além das idéias da Prática de Administração. $O$ enfoque do livro é mercadológico. Fala-se mais na maximização de oportunidades do que na solução de problemas, que era uma frase preferida dos homens de emprêsa até recentemente. Vindo depois de Fronteiras do Amanhã, o livro parece voltado para as perspectivas do futuro. $O$ futuro não será feito amanhã. Está sendo feito hoje em grande parte pelas decisões $\mathrm{e}$ ações tomadas com respeito às tarefas de hoje.

O EXECUTIVO PACIENTE

Em 1967, a obra seguinte de DRUCKER, The Effective Executive ${ }^{31}$ pretende ser uma continuação de Managing for Results, focalizando, tão perto como nunca foi, a eficiência dos dirigentes. O campo da técnica de chefia, que até recentemente estava abandonado a escritores de segunda classe que produziam verdadeiros livros de receitas, vem sendo objeto de estudo de autores como DRUCKER, MCGREgor e outros. Por sua parte, DRUCKER oferece neste livro conceitos muito práticos e operacionais, os quais, ao mesmo tempo, estão em perfeito acôrdo com a sua filosofia da administração.

$\mathrm{Na}$ introdução, o autor observa que é comum encontraremse executivos de boa inteligência, sólido conhecimento da função, pessoas brilhantes e imaginativas. No entanto, poucas dessas pessoas são eficientes. Confundem-se inteligência e eficiência, quando se conhece muita gente com a primeira qualidade e sem a segunda. $O$ mesmo se pode dizer das outras qualidades acima apontadas. Estamos cansados de executivos bem dotados, mas ineficientes.

3t Druckar, Peter F., The Effective Executive, New York, Harper \& Row, 1967. Este livro está sendo traduzido para o português. 
O autor estuda "o que os executivos eficientes fazem, que nós não fazemos, e o que êles não fazem, que nós tendemos a fazer". O livro gira em tôrno da idéia central que é: a eficiência é um hábito, não uma qualidade herdada naturalmente. A eficiência pode ser aprendida.

$O$ que se exige de um trabalhador subalterno é que faça bem o que deve fazer, enquanto que o executivo deve fazer certo as coisas certas. Grande parte da eficiência não é representada pelo próprio desempenho dos atos, mas pela escolha do alvo certo onde concentrar suas energias. Nada mais triste do que observar um inteiro departamento de engenheiros desperdiçar seu talento num projeto errado. Outro aspecto da eficiência é olhar para fora da organização: "Todo executivo, seja sua organização uma emprêsa de negócios, um laboratório de pesquisas, uma agência do govêrno, uma grande universidade ou a fôrça aérea, vê $o$ interior - a organização - como a realidade próxima e imediata. Êle vê o exterior sòmente através de lentes espêssas e destorcidas. O que acontece fora não é nem mesmo conhecido em primeira mão. É recebido por um filtro de relatórios, isto é, numa forma pré-digerida e altamente abstrata que impõe critérios organizacionais de relevância à realidade externa." ${ }^{32}$

Ora, como se sabe, "não há resultados dentro da organização. Todos os resultados estão fora. Os únicos resultados do negócio são produzidos por um consumidor que converte os custos e esforços do negócio em dividendos e lucros". ${ }^{33}$

O problema é que os eventos externos importantes e relevantes são freqüentemente qualitativos e não passíveis de serem quantificados. E nossos executivos estão cada vez mais dominados pelo ópio intelectual da estatística a ponto de não serem capazes de enxergar nada além das tendências estatìsticamente demonstradas. Ora, os verdadeiros eventos externos não são tendências, são mudanças

Idem, ibidem, p. 13 .

Idem, ibidem, p. 13. 
nas tendências. Algumas decisões que dependem da estatística são tardias. $O$ fracasso do Ford Edsel, um carro inteiramente planejado, deve-se ao fato de não se terem levado em conta as mudanças qualitativas no gôsto do consumidor. A talidomida foi uma droga monstruosa, sendo retirada do mercado graças à luta empreendida por uma médica que interpretou as mudanças de forma qualitativa. Quantas criaturas infelizes teriam nascido até que se fôsse esperar pelas tendências estatísticas?

A eficiência executiva não é pois igual à eficiência comum dos empregados. Não sendo a eficiência executiva uma aptidão natural ela é um hábito a ser adquirido. Quais são as práticas que levam à aquisição dêste hábito? O livro de DRUCKer desenvolve-se na resposta a essa pergunta. Cinco são os princípios gerais da eficiência:

- Saber onde gastar o próprio tempo.

- Concentrar esforços em resultados mais do que em trabalho.

- Basear-se nas qualidades pessoais mais fortes.

- Concentrar-se nas tarefas-chave.

- Tomar decisões efetivas.

Saber onde gastar seu tempo é uma posição necessária para o executivo eficiente. Por mais que se busque uma forma de estender o tempo de trabalho prolongando-o após o expediente, chegando mais cedo, trabalhando à noite em casa, ou no fim de semana - o tempo é inelástico e sólido. O tempo não se estende na proporção dos desejos do executivo. O que se pode fazer é cortar as tarefas menos importantes. "Em todo cargo executivo, uma grande parte do tempo é gasta em coisas que, apesar de precisarem ser 
feitas, em pouco ou nada contribuem." ${ }^{34}$ Para reduzir o tempo gasto o autor recomenda algumas perguntas :

- O que aconteceria se eu não fizesse isto?

- Qual das minhas tarefas pode ser feita por outra pessoa tão bem ou melhor do que eu?

- O que eu faço que toma o tempo dos outros?

Em seguida, o autor recomenda diversos procedimentos. para a economia do tempo. Fazer com que sua secretária anote num dia típico todos os seus compromissos e a duração. Reduzir o tempo que se gasta dentro da firma em "relações humanas" (interacting). Reduzir o número de subordinados ou a amplitude de contrôle. Nunca tomar decisões sôbre pessoas na primeira vez que surge o problema. Reduzir as reuniões. Estabelecer uma duração para reuniões, entrevistas e decisões, completada a qual se transfere automàticamente o assunto para o dia seguinte. Melhorar as comunicações cujas falhas causam grande perda de tempo. E não levar trabalho para fazer à noite em casa: nessa hora as faculdades mentais estão menos. ágeis do que pela manhã.

$\mathrm{Na}$ obra anterior de DRUCKer já se tinha lido sôbre "concentrar esforços em resultados mais do que em trabalho". Êste é o enfoque da contribuição: "Como eu posso contribuir para melhorar os resultados da emprêsa? Por que eu sou pago? O que significa que eu esteja na fôlha de pagamento?" $O$ enfoque na contribuição volta a atenção do executivo para fora de sua especialidade, de suas limitadas habilidades, de seu departamento, na direção do todo. Volta a sua atenção para fora, o único lugar onde há resultados.

"A única significativa definição de generalista é: um especialista que pode relacionar sua emprêsa com o universo do conhecimento. Êle cedo percebe que precisa aprender mais sôbre as necessidades, direções, limitações e percepções dos outros para habilitá-los a usar o seu próprio

a Idem, ibidem, p. 28. 
trabalho. Mesmo que isso não o faça apreciar a riqueza e excitação da diversidade, dar-lhe-á imunização contra a "arrogância dos instruídos", essa doença degenerativa que destrói o conhecimento e lhe tira a beleza e a eficiência." ${ }^{35}$

$O$ terceiro princípio da eficiência executiva é basear-se nas qualidades pessoais mais fortes (building on strengths). Aqui, o autor combate o mito do "homem integral" ou da "personalidade equilibrada" argumentando que as pessoas dificilmente têm uma balança de qualidades em perfeito equilíbrio. Em cada pessoa umas qualidades superam outras. Alguns homens passam a vida tentando corrigir pequenas fraquezas, desperdiçando o tempo que poderiam dedicar a realizar suas grandes qualidades potenciais. "Um bom contador pode ter dificuldades em virtude da sua inabilidade em lidar com pessoas. Numa organização, tal homem pode ser colocado numa sala à parte $\mathrm{e}$ ter reduzido o seu contato com pessoas de modo a poder dar o máximo de contribuição. Numa organização uma pessoa pode tornar sua fôrça mais eficiente e sua fraqueza sem importância." ${ }^{36}$

Existe em inglês um provérbio que representa essa verdade: One cannot hire a hand, the whole man always comes with it. Por isso ao julgar um homem não se deve perguntar: Como êle se dá comigo? Mas, sim: Com que êle contribui? Não se deve perguntar: Quem está certo? Mas, sim: $\mathrm{O}$ que é certo?

Quando se está diante de uma tarefa complexa, deve-se começar pelo que a pessoa pode fazer e não com aquilo que o cargo exige. $O$ cargo, muitas vêzes, deve ser redesenhado em função do ocupante. $O$ administrador deve esquecer as fraquezas humanas e concentrar-se nos recursos pessoais. A tarefa do executivo não é mudar as pessoas, mas multiplicar o desempenho.

35 Idem, ibidem, p. 63.

is Idem, ibidem, p. 75 . 
Concentrar-se nas áreas-chave é um quarto aspecto da eficiência executiva. "Fazer as primeiras coisas primeiro e nunca as segundas" é um provérbio que ensina que o segrêdo do sucesso é a concentração nos alvos vitais. Há pessoas que trabalham àrduamente sem contudo nada fazer. Há pessoas numa emprêsa que passam o tempo inventando coisas para fazer. Isto nos leva a crer que o trabalho não é necessàriamente ligado a resultados. $O$ autor dá alguns conselhos a êsse respeito: o executivo deve romper com o "ontem" e livrar-se de fracassos que as pessoas continuam a remediar sem resultado. $O$ executivo deve conceber cada trabalho como provisório e expirando dentro de um prazo; qualquer tarefa só deve ser continuada se houver justificativa econômica. $O$ executivo não deve perder o tempo tentanto resolver problemas: " $\mathbf{E}$ mais produtivo converter oportunidades em resultados do que resolver problemas, que apenas restitui o equilíbrio de ontem."

Finalmente, o quinto princípio da eficiência executiva é tomar decisões efetivas. Bons executivos raramente tomam decisões porque o quotidiano requer mais aplicação de políticas do que tomada de decisões. Toma-se uma decisão quando o evento é único e não se enquadra dentro das políticas anteriormente definidas. Ora, os eventos únicos são extremamente raros, enquanto que os fatos diários são variações de fatos já conhecidos, e sôbre os quais existem fórmulas estabelecidas. $O$ executivo que toma decisões a cada momento é aquêle que considera "cada caso um caso". Dentro dêsse pragmatismo, êle é incapaz de distinguir características genéricas e repetitivas, de características individuais. $\mathrm{Na}$ interpretação dos fatos da emprêsa e do mercado, o executivo deve-se perguntar: Trata-se de uma situação genérica ou de uma exceção? Êste caso é uma verdadeira exceção, o nascimento de um nôvo gênero?

A incompetência do executivo, sua ineficiência e desperdício de tempo, devem-se ao fato de tratar cada caso como um caso. Um provérbio inglês diz que "um país de dema- 
siadas leis é um país de advogados incompetentes". Do mesmo modo, um executivo que gasta demasiado tempo tomando muitas decisões é um executivo desorganizado, que não formulou políticas nem distinguiu níveis de decisão entre si e os subordinados.

Outro aspecto das decisões é o do acôrdo nas reuniões. Há hoje uma pressa em concordar com a opinião predominante e êsse é um grave conformismo que grassa nas organizações. É preciso preservar a oposição construtiva e o desacôrdo. Onde há dissenção lança-se mais luz sôbre os fatos e sôbre as posições de cada um. $O$ autor cita o exemplo de um executivo que, observando uma reunião chegar a um prematuro acôrdo geral, cortou a reunião inesperadamente desta forma: "Meus senhores, vamos suspender esta reunião e marcar uma próxima para que os senhores tenham tempo de se porem em desacôrdo". A isso o autor chama de "arte do desacôrdo organizado". No entanto, DRUCKER recomenda cautela sôbre o manejo do desacôrdo a fim de evitar que as pessoas o compreendam mal. Alguns biógrafos de Roosevelt citam testemunhos de pessoas que com êle trabalharam, que se queixavam de que êle atritava a umas contra as outras para daí derivar suas decisões.

O Executivo Eficiente é um livro prático para uso imediato, repousa numa linha de idéias que começou na Prática da Administração e se desenvolveu na Administração para Resultados. A idéia central é a de que o esfôrço humano é mais compensador quando concentra suas energias nos alvos vitais da organização.

CONCLUSÃO: A EPOCA E O HOMEM

O leitor que seguiu até aqui a análise de todos os livros de DRUCKer gostaria de encontrar uma síntese de seu pensamento. Para se fazer o retrato de um homem é preciso buscar o ambiente cultural em que êle se coloca $\theta$ julgá-lo dentro de um conjunto de fôrças que caracterizam sua época. Nesses setenta anos de desenvolvimento da 
emprêsa moderna, a teoria da administração pode ser classificada em três etapas:

- a era tayloriana ou de racionalismo primitivo;

- a antítese feita pela era das "relações humanas"; e

- a síntese, produzida após a Segunda Guerra Mundial, que representa um neo-racionalismo.

A era de TAYLOR e FAYOL deu uma contribuição racionalista para o estudo do trabalho. Introduziu o conceito de mensuração e estabeleceu princípios de direção industrial. Mas, ao mesmo tempo, deixou com a divisão de trabalho algumas debilidades: o trabalhador isolou-se do produto final e os compartimentos estanques de uma organização em crescimento foram mostrando uma grande falta de integração. $O$ antigo empresário que aderiu à divisão do trabalho como exigência da produção em massa enfrentou o desafio representado pela crescente funcionalização e pela quase explosão das especialidades.

A escola das "relações humanas", surgida no bôjo das resistências contra os efficiency experts de TAYLOR, representa, na primeira fase, uma reação (antítese) contra o racionalismo da emprêsa "econômica". Emergem os estudos sôbre a subjetividade do trabalhador, suas necessidades e satisfações pessoais. $\mathrm{Na}$ emprêsa, como comunidade social, surge a escola personalista de liderança. Dentro do mesmo enfoque "humano", a escola das relações humanas é sucedida pelo enfoque das behavioral sciences que são científicas quanto ao método de pesquisa, mas falham como um sistema global. Os métodos de laboratórios para estudo de liderança e atitudes são "científicos", mas não chegam a superar o âmbito do pequeno grupo. Além do mais, as "relações humanas" e "ciências do comportamento" falham em ver a emprêsa como um sistema de esforços conjugados para atingir objetivos econômicos.

Dez anos após a Segunda Guerra Mundial, a decadência da escola das relações humanas é um sintoma de um 
neo-racionalismo. Volta-se à emprêsa como organização racional. Surge SIMON e os modelos teóricos. A escola "matemática". A teoria dos jogos. Os próprios cientistas do comportamento se voltam para modelos teóricos de simulação. $\mathrm{Na}$ administração geral ressurge a preocupação pelos resultados do negócio. Administração por objetivo e para resultados. A liderança "democrática" de LEWIN, acadêmica e pouco testada no âmbito industrial, é substituída pelos padrões de liderança de TANNENBAUM; também êle um antigo discípulo das "relações humanas". Fala-se em "liderança voltada para a realidade". A preocupação por resultados leva ao desenvolvimento de objetivos quantitativos e a padrões de desempenho. $O$ personalismo, tão caro à escola de "relações humanas", decai e é substituído pela preocupação pelo desempenho. $O$ desempenho objetivo eclipsa a personalidade.

Dentro dêsse vasto quadro histórico, DRUCKER traz a contribuição para compreender a emprêsa como uma organização racional do esfôrço humano conjugado. Sua recusa em aceitar as proposições da escola de relações humanas aparece em vários livros. $\mathrm{Na}$ obra de DRUCKER aparecem dois temas fundamentais:

a moderna corporação industrial é representativa de nossa época e sua forma de trabalho constitui um modêlo de organização do esfôrço humano para outras organizações não-industriais, como o Exército, a Igreja Católica, a Universidade e o Grande Hospital;

- tornar a alta administração mais eficiente é uma importante tarefa de nosso tempo, e isto é conseguido concentrando-se os esforços individuais em tôrno dos objetivos da organização e estabelecendo-se medidas objetivas para a avaliação dêsses esforços.

No estudo da experiência da General Motors, percebeu êle que a descentralização precisava ser acompanhada de objetivos e de medidas quantitativas do desempenho. Os objetivos asseguram que os administradores são educados 
para ter uma visão global da organização. Essa "atitude gerencial" é necessária para que o empregado e especialmente a média administração vejam a emprêsa como um todo e superem as limitações óticas do especialista. $\mathrm{Na}$ "prática", o autor elabora um conjunto de objetivos de emprêsa em função dos setores-chave. O esfôrço dos administradores superará o impasse da "divisão do trabalho" tayloriana, quando êsse esfôrço fôr concentrado nos setores-chave do negócio. $O$ papel do administrador aumentou de importância nesse mundo que é a fronteira do amanhã.

O administrador é chamado a coordenar complexas especialidades e, em seu papel de integrador de esforços coletivos, êle deve ter uma formação liberal.

Espera-se que o administrador se preocupe menos com trabalho e mais com resultados. Rompendo com o passado, o homem deve concentrar seus esforços não em resolver problemas mas em explorar oportunidades. O homem, voltado para as oportunidades, deve saber analisar as perspectivas e distinguir as tendências dos eventos novos e únicos, início de nôvo gênero. A eficiência do homem depende da escolha das tarefas-chave e da concentração de esforços nos recursos de cada um e nas oportunidades que geralmente estão fora da emprêsa.

O notável impacto das idéias de DRUCKER sôbre seus contemporâneos pode ser apreciada na vasta bibliografia de administração de nossos dias. Nenhum tratado de administração deixa hoje de comentar sôbre objetivos da emprêsa. Nenhuma obra sôbre planejamento a longo prazo, diretrizes administrativas ou estratégia corporativa deixa de transcrever alguns trechos de suas idéias. Todavia, é ainda cedo para uma apreciação objetiva e distante. Peter F. Drucker tem uma obra em progresso, que avança cada ano, superando seus próprios desafios. 


\section{BIBLIOGRAFIA DE PETER F. DRUCKER}

(Incluindo apenas os livros)

1939 - The End of the Economic Man, Londres, Heineman.

1943 - The Future of the Industrial Man, Londres, Heineman.

1946 - The Concept of the Corporation, Nova Iorque, John Day. Sem tradução em português.

1950 - The New Society. Tradução brasileira A Nova Sociedade, Rio de Janeiro, Editôra Fundo de Cultura, 1964.

1954 - The Practice of Management, Nova Iorque, Harper and Row. Traduzido em português: Prática de Administração de Emprêsas, 2 volumes, Rio de Janeiro, Editôra Fundo de Cultura, 1962.

1957 - America's Next Twenty Years, Nova Iorque, Harper and Row. Sem tradução em português.

1959 - Gedanken für die Zukunft, Düsseldorf, Econ Verlag. Sem tradução em português.

1960 - Landmarks of Tomorrow, Nova Iorque, Harper and Row. Tradução em português: Fronteiras do Amanhã, Rio de Janeiro, Editôra Fundo de Cultura, 1964.

1964 - Managing for Results, Nova Iorque, Harper and Row. Traduzido em português: Administração Lucrativa, Rio de Janeiro, Zahar Editôres, 1968 .

1967 - The Effective Executive, Nova Iorque, Harper and Row; está sendo traduzido para o português pela Editôra Fundo de Cultura, Rio de Janeiro.

DRUCKER tem em preparação um nôvo livro que êle considera uma continuação dos temas de Fronteiras do Amanhã. 